\title{
Geomorphic evidence for Plio-Quaternary compression in the Andean foothills of the southern Neuquén Basin, Argentina
}

\author{
G. Messager, ${ }^{1}$ B. Nivière, ${ }^{1}$ J. Martinod, ${ }^{2}$ P. Lacan, ${ }^{1}$ and J.-P. Xavier ${ }^{3}$ \\ Received 1 September 2009; revised 24 January 2010; accepted 15 February 2010; published 13 July 2010.
}

[1] The southern central Andes foothills are made of imbricate thick- and thin-skinned fold and thrust belts. They were formed during Cretaceous and Miocene compressive periods by successive eastward propagation episodes of the orogenic front. We analyze remnant terraces and alluvial deposits of the Neuquén River and its tributaries to study the Plio-Quaternary tectonic regime in the southern Neuquén Basin. Topographic profiles of remnant terraces show a crustal-scale (tens of kilometers) anomaly above the Chihuido South anticline. This anomaly is accompanied by sedimentary aggradations downstream and upstream of the anticline. Another anomaly in the terrace profiles, correlated with a knickpoint in the current Neuquén River, is observed farther east, near Añelo. We interpret these anomalies to be the consequence of a Plio-Quaternary uplift of the Chihuidos and Añelo anticlines. Folding and surface faulting of Plio-Quaternary alluvial deposits show that this uplift is concomitant with the reactivation of the Miocene orogenic front and of the predominantly thin-skinned Agrio fold-and-thrust belt. From these data we infer that the southern Neuquén Basin is still shortening under a compressive stress regime and that the Andean orogenic front is migrating farther to the east. Extensional features in the study area correspond mainly to thin-skinned gravitational gliding, resulting from crustal uplift. Thus, we argue that the tectonic compressive regime is preserved in the southern Neuquén Basin throughout the Plio-Quaternary, though the slab may have steepened during this period. Citation: Messager, G., B. Nivière, J. Martinod, P. Lacan, and J.-P. Xavier (2010), Geomorphic evidence for PlioQuaternary compression in the Andean foothills of the southern Neuquén Basin, Argentina, Tectonics, 29, TC4003, doi:10.1029/2009TC002609.

\section{Introduction}

[2] In some subduction zones, the overriding plate has been subject to shortening, whereas in others it has undergone back-arc extension. The main controlling factors

\footnotetext{
${ }^{1}$ Modeling and Imagery in Geosciences, University of Pau, CNRS, Pau, France.

${ }^{2}$ LMTG, University of Toulouse, CNRS, IRD, Toulouse, France.

${ }^{3}$ CSTJF, Total, Pau, France.

Copyright 2010 by the American Geophysical Union. 0278-7407/10/2009TC002609
}

would appear to be the dip of the subducting slab [e.g., Jordan et al., 1983; Jarrard, 1986], the absolute plate motion and the degree of coupling between the overriding and subducting plates [Russo and Silver, 1996; Gutscher et al., 2000b; Lamb and Davis, 2003; Lallemand et al., 2005; Hampel and Pfiffner, 2006; Oncken et al., 2006; Schellart et al., 2007, 2008]. The interplay between the subducting and overriding plates drives buildup of the foreland and may result in alternating periods of extension, quiescence and compression [e.g., Sdrolias and Müller, 2006; Clark et al., 2008].

[3] Concerning the southern central Andes, some authors interpret the alternation of tectonic regimes since the Cretaceous in relation to changes in plates kinematics and slab dip [e.g., Pardo-Casas and Molnar, 1987; Jordan et al., 2001; Charrier et al., 2005; Ramos and Folguera, 2005; Kay et al., 2006; Burns et al., 2006]. But the relationship between the subduction dynamics and the intraplate shortening is not straightforward as plate coupling is controlled by many different, interacting factors [e.g., Jordan and Allmendinger, 1986; Pardo-Casas and Molnar, 1987; Cahill and Isacks, 1992; Silver et al., 1998; Gutscher et al., 2000a, 2000b; Lamb and Davis, 2003; Ramos and Folguera, 2005; Vietor and Echtler, 2006; Schellart, 2008; Guillaume et al., 2009b]. The Plio-Quaternary state of stress and deformation in the southern central Andes, along the Neuquén Basin of Argentina, is therefore a subject of debate. Ramos and Folguera [2005] and Folguera et al. [2007b, 2008] argue that an extensional state of stress in the Andean Cordillera and foothills is producing a regional collapse. The extension is discussed in the thematic studies cited above and is based on two sets of geological evidence. As the distance from the volcanic arc to the trench is related to slab dip, eastward and westward migration of the arc denotes, respectively, shallowing and steepening of the slab [Stern, 1989; Ramos and Folguera, 1999; Kay, 2002; Ramos and Folguera, 2005; Kay et al., 2006]. The steepening of the subduction zone and the slab roll-back would have favored a crustal back-arc extension [Ramos and Folguera, 2005; Ramos and Kay, 2006; Lara and Folguera, 2006; Folguera et al., 2006, 2007b, 2008]. According to Folguera et al. [2007b, 2008], crustal normal faults and extensional troughs control the emplacement of back-arc volcanism attesting to a MioPleistocene extensional event. Cobbold and Rossello [2003], Galland et al. [2007b] and Guzmán et al. [2007], on the other hand, postulate that the stress regime remains mainly compressive. In particular, Marques and Cobbold [2002], Cobbold and Rossello [2003], Backé [2006] and Galland et al. [2007b] describe coeval compressive features in this area. In this paper, we discuss the Plio-Quaternary tectonic regime of the overriding plate in the southern Neuquén Andes 


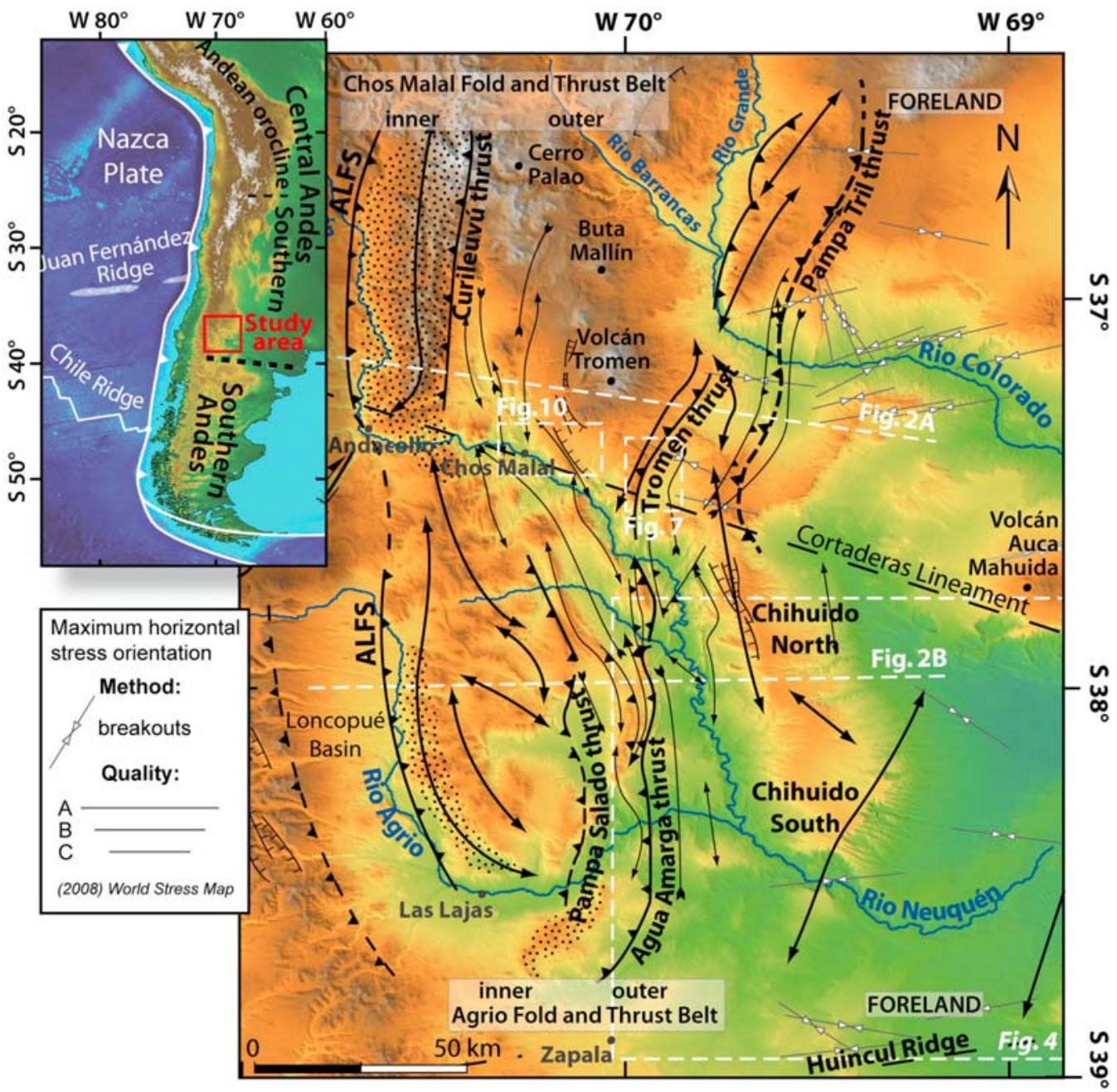

Figure 1. Structural sketch map of the studied area. Thin and thick arrows refer to the thin- and thickskinned structures. Dots represents the outcrops of pre-late Jurassic basement rocks. The directions of the maximum horizontal stress are from 27 borehole breakouts cited by Guzmán et al. [2007] (data available on the Web site of the World Stress Map (WSM): http://dc-app3-14.gfz-potsdam.de/pub/stress_data/ stress_data_frame.html/). Quality coding is labeled from the best (A) to the worst data (C) using the WSM criteria. Inset is location of the Neuquén Basin.

during the slab roll-back episode. We use morphological markers, such as remnant terraces of the Neuquén River and alluvial fans. We argue that the Chihuidos area $\left(69^{\circ} \mathrm{W}, 39^{\circ} \mathrm{S}-\right.$ $70^{\circ} \mathrm{W}, 37^{\circ} 20^{\prime} \mathrm{S}$ ) was uplifting during the Plio-Quaternary.

\section{Morphological and Geological Settings}

\subsection{Morphostructural Setting}

[4] The Neuquén Basin is a triangular basin located in the Andean foreland of western Argentina, between $36^{\circ} \mathrm{S}$ and $40^{\circ} \mathrm{S}$ (Figure 1). It appeared as a back-arc basin east of the Andean volcanic arc. Three extensional episodes between the Carboniferous and early Cretaceous times resulted in NW-SE oriented grabens and half grabens [Ramos, 1976; Uliana et al., 1989; Mpodozis and Kay, 1992; Vergani et al., 1995; Zapata et al., 1999; Franzese and Spalletti, 2001]. These were inverted following the opening of the southern
Atlantic Ocean, $100 \mathrm{Ma}$ ago. The basin contains a sequence of marine and continental deposits more than $7 \mathrm{~km}$ thick.

[5] The study area comprises the Loncopué Basin in the west and the Chos Malal and Agrio fold-and-thrust belts in the east (Figures 1 and 2). At the eastern toe of the volcanic arc, the Loncopué Basin extends north-south over more than $200 \mathrm{~km}$. Its elevation decreases to the south, from approximately 1600 to $1000 \mathrm{~m}$.

[6] The transverse Cortaderas Lineament is the boundary separating the Chos Malal fold-and-thrust belt to the north from the Agrio fold-and-thrust belts to the south (Figure 1) [Groeber, 1929; Ramos, 1981]. The fold-and-thrust belts either side of it have common features. Back in the Cretaceous, they already had a thick-skinned inner domain and a thin-skinned outer one (Figures 1 and 2) [Ramos, 1978]. The inner domain contains broad anticlines, approximately $100 \mathrm{~km}$ long and $30 \mathrm{~km}$ wide, above west and east dipping 
A. Structural cross section at $37^{\circ} 15^{\prime} \mathrm{S}$

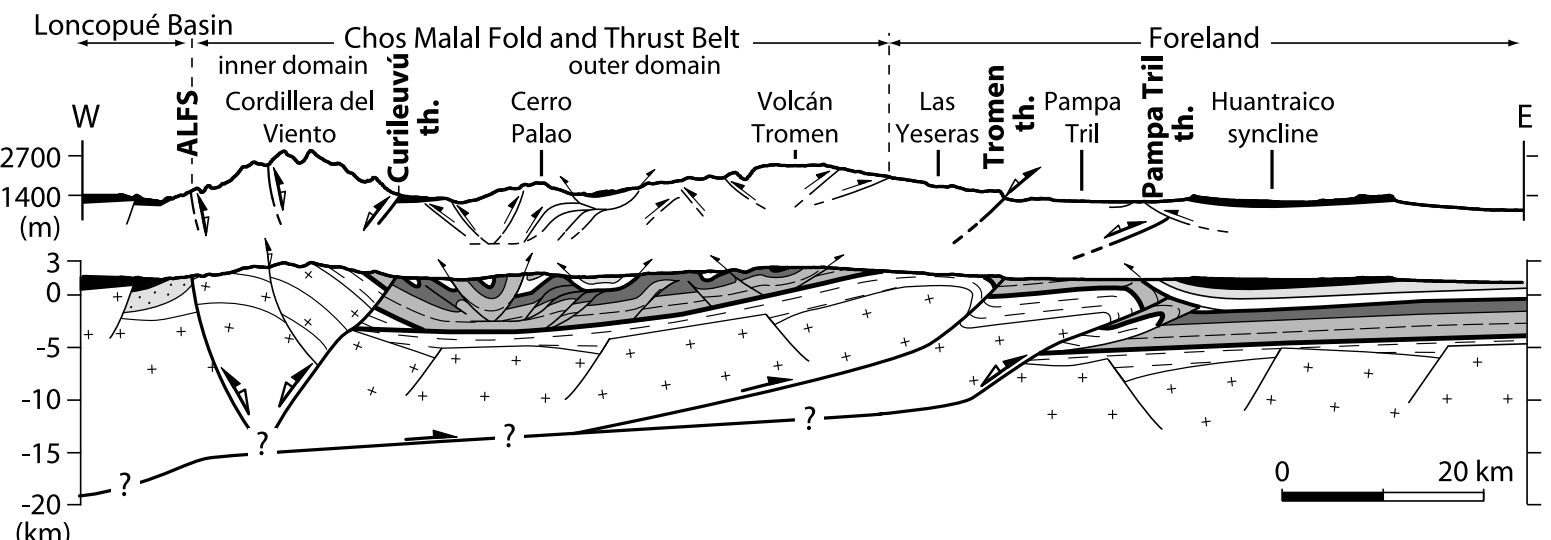

\section{B. Structural cross section at $38^{\circ} \mathrm{S}$}

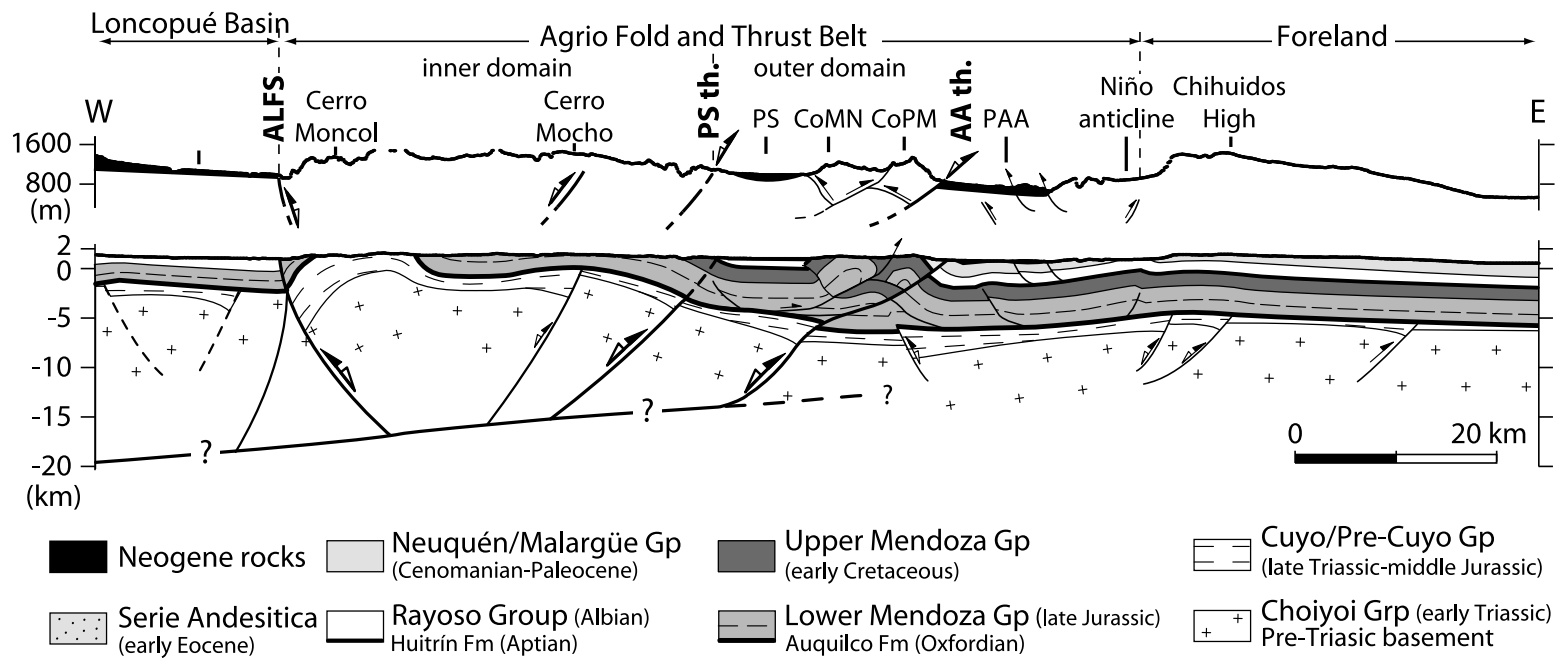

Figure 2. East-west structural cross sections. (a) Across the Chos Malal fold-and-thrust belt $\left(37^{\circ} 15^{\prime} \mathrm{S}\right)$ [after Vergani et al., 1995; Kozlowski et al., 1996; Cobbold et al., 1999; Zamora Valcarce et al., 2006b; Folguera et al., 2007a]. (b) Across the Agrio fold-and-thrust belt (38 ${ }^{\circ}$ S) [after Zapata et al., 2003; Cobbold and Rossello, 2003; Zamora Valcarce et al., 2006a]. ALFS, Andacollo-Loncopué Fault System; PS, Pampa del Salado; CoMN, Cerro Mula-Naunauco; CoPM, Cerro Pichi Mula; AA, Agua Amarga; PAA, Pampa de Agua Amarga; th., thrust; Gp., group; Fm, formation. Locations are indicated by boxes in Figure 1. The extent of crustal features at depth remains unknown. For the shake of simplicity, we present a basal detachment at the limit upper/lower crust. Moreover, there is no consensus regarding vergence of the main thrust beneath the Cordillera del Viento. Kozlowski et al. [1996] and Folguera et al. [2007a] invoke an eastward verging trend, in opposition to Zapata et al. [1999] and Cobbold et al. [2008].

crustal thrusts. The outer domain is composed of large, doubly plunging and short-wavelength anticlines, only $30 \mathrm{~km}$ long and $10 \mathrm{~km}$ wide (Figure 2) [Bracaccini, 1970; Vergani et al., 1995; Kozlowski et al., 1996; Zapata et al., 1999; Cobbold and Rossello, 2003; Zamora Valcarce et al., 2006a]. These developed above the Auquilco evaporites (Upper Jurassic, Figure 3) and the shale of the Vaca Muerta Group (Late Jurassic, Figure 3 [Viñes, 1985; Ramos, 1988; Kozlowski et al., 1996]). Examined in greater detail, the inner Chos Malal fold-and-thrust belt is restricted to the Cordillera del Viento, $20 \mathrm{~km}$ wide and nearly $3000 \mathrm{~m}$ high (Figures 1 and 2a), where late Triassic to early Jurassic rocks crop out (Pre-Cuyo and Cuyo groups; Figure 3). The outer domain is wider $(50 \mathrm{~km})$ and its average topographic elevation is lower (roughly $2000 \mathrm{~m}$ ) than its inner counterpart. It ends to the east in the Tromen volcano area. The average topographic elevation of the Agrio fold-and-thrust belt is lower and reaches only $1500 \mathrm{~m}$ (Figure 2b). Limited to the east by the Pampas de Naunauco and del Salado (PS in Figure 2b), its inner domain is wider (around $40 \mathrm{~km}$ ) than to the north and also exhibits the early Jurassic basement rocks (PreCuyo Group, Figure 3). Its outer domain is limited by a set 


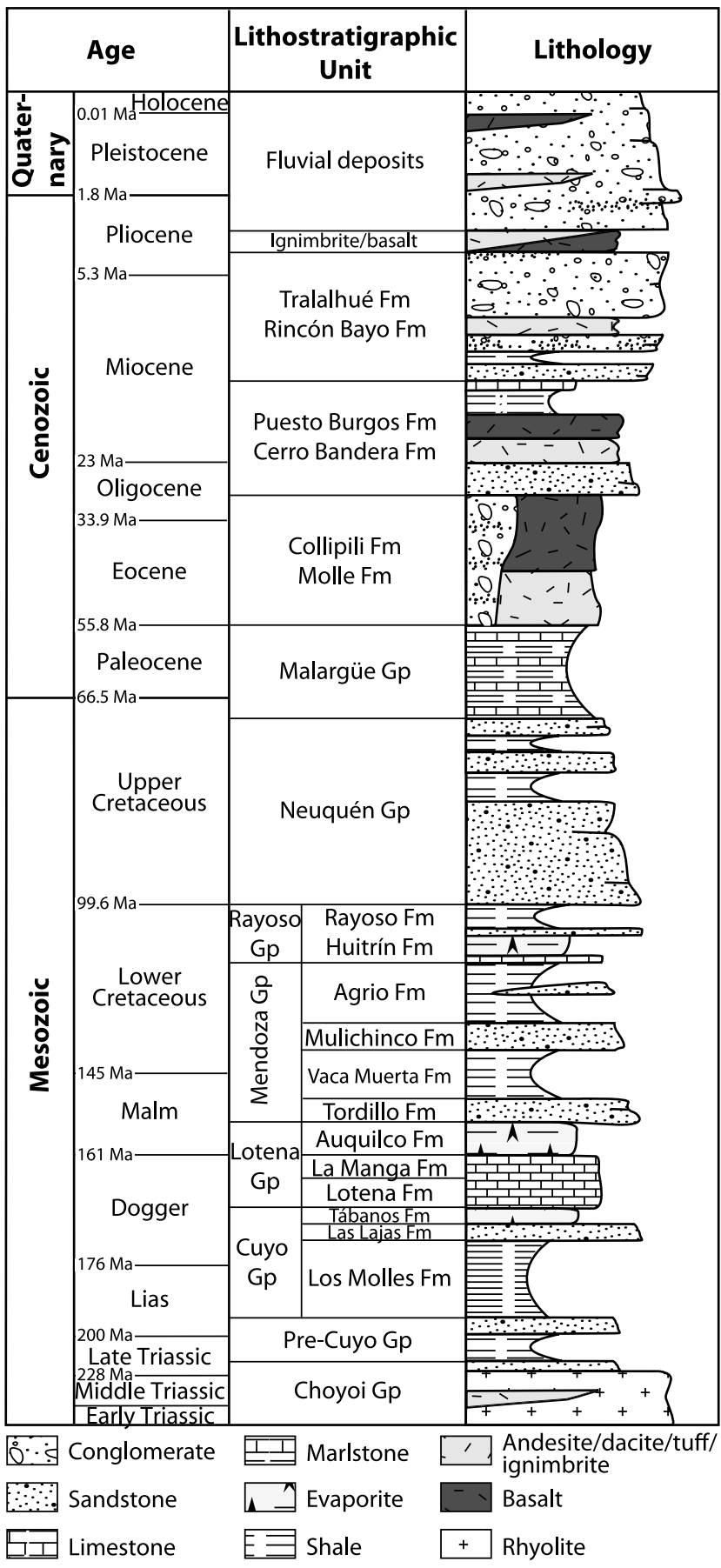

Figure 3. Stratigraphic column of the southern Neuquén Basin. After Holmberg [1964, 1976], Zöllner and Amos [1973], Ramos [1981], and Leanza and Hugo [1999]. Fm, Formation; Gp, Group. No time or thickness scales are represented. of north-south trending anticlines (Figure 1). The Niño anticline lies above the Chihuidos High to the north (Figures $2 \mathrm{~b}$ and 4), and the Cerro Negro anticline extends in the Pampa de Agua Amarga to the south (Figures 1 and 4).

[7] East verging crustal thrusts cut through the outer domain of the Chos Malal and Agrio fold-and-thrust belts. To the north, at the eastern toe of the Tromen volcano, the crustal Tromen thrust extends over $70 \mathrm{~km}$ and is arcuate around the volcano [Bracaccini, 1970; Kozlowski et al., 1996; Marques and Cobbold, 2002] (Figures 1 and 2a). It is relayed to the east by the Pampa Tril blind thrust (Figure 2a) [Vergani et al., 1995; Kozlowski et al., 1996]. The Agua Amarga thrust continues the Tromen thrust over $100 \mathrm{~km}$ to the south (Figures 1 and 2b) [Zapata et al., 2003]. To the east of the thin-skinned Agrio fold-and-thrust belt stands the $150 \mathrm{~km}$ long and 40-60 km wide Chihuidos High (Figure 1). This is one of the most prominent features of the area and is interpreted as a basement-cored anticline (Figure 2b) [Cobbold and Rossello, 2003; Mosquera and Ramos, 2006]. The current relief delimits a northern segment, trending $\mathrm{N} 170^{\circ} \mathrm{E}$, hereafter labeled as the Chihuido North anticline, and a southern $\mathrm{N} 30^{\circ} \mathrm{E}$ trending segment, labeled as the Chihuido South anticline. A subsidiary oblique topographic high, oriented $\mathrm{N} 160^{\circ}$, is found between the two anticlines (Figures 1 and 4). As their western flank is steeper (around $20^{\circ}$ to the west versus $4^{\circ}$ to the east), the Chihuidos anticlines are interpreted as west verging [e.g., Mosquera and Ramos, 2006].

[8] The Neuquén River is the main drainage channel of the study area (Figure 1). It flows north-south in the Loncopué Basin after which it follows the Cortaderas Lineament from the Cordillera del Viento to the Tromen thrust (Figure 2). It runs north-south again along the western limb of the Chihuidos anticlines within the Agua Amarga syncline. From here, it flows eastward across the southern end of the Chihuido South anticline in a narrow, embanked valley before eventually veering northeast as far as Añelo and then southeast to Neuquén City.

\subsection{Inversion of the Mesozoic Basin}

[9] The Mesozoic basin has been inverted in compression since the middle Cretaceous [e.g., Windhausen, 1914; Keidel, 1925; Groeber, 1929; Wichmann, 1934]. Variations in displacements trends and velocities of the Farallon and South American plates controlled three compressive episodes, the Peruvian, Incaic and Quechua phases [e.g., Steinmann, 1929; Pardo-Casas and Molnar, 1987; Cobbold and Rossello, 2003].

[10] The Peruvian phase (middle to late Cretaceous) started contemporaneously with the opening of the South Atlantic Ridge. An increasing convergence rate and shallowing of the Benioff Zone [Pardo-Casas and Molnar, 1987; Somoza, 1998; Kay, 2005] resulted in a compressive regime which

Figure 4. Map of the Plio-Quaternary remnant terraces of the Neuquén River. Brackets in color bar refer to elevations of the remnant terraces. The dashed segmented line corresponds to the projection axis along which river, and the average elevations of terraces have been orthogonally projected in Figure 5. Letters a to $\mathrm{m}$ are locations of some remnant terraces projected in Figure 5. The arrow points to the Añelo knickpoint (AñK). 


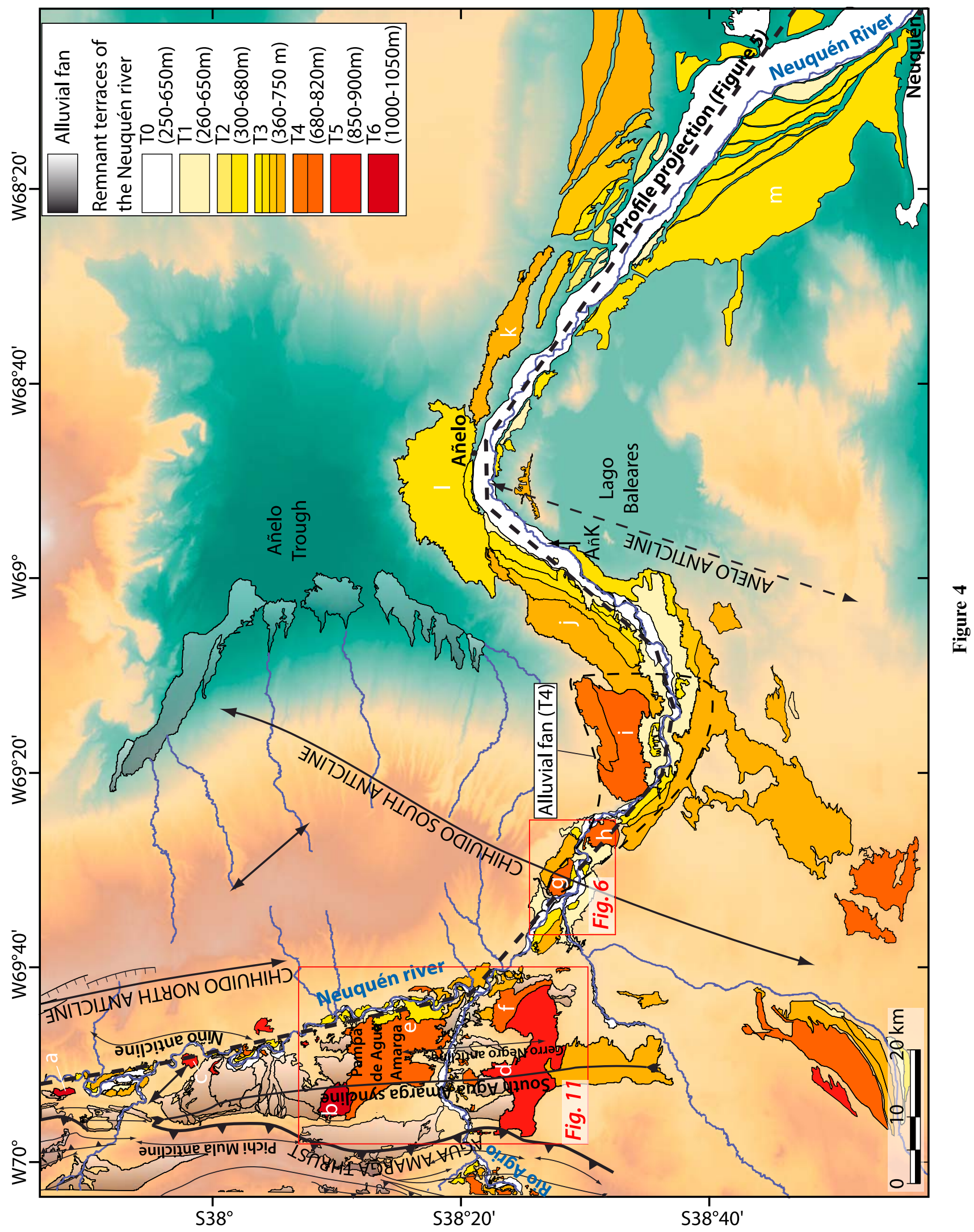


reactivated former Jurassic normal faults [Vergani et al., 1995; Kozlowski et al., 1996]. This led to the buildup of the Chos Malal and Agrio fold-and-thrust belts in the middle to late Cretaceous times [e.g., Groeber, 1929; Bracaccini, 1970; Llambias, 1986; Kay, 2001; Jordan et al., 2001; Burns, 2002; Cobbold and Rossello, 2003]. According to Kozlowski et al. [1996] and Folguera et al. [2007a] the crustal orogenic front was eastward verging on the eastern side of the Cordillera del Viento (Curileuvú thrust; Figure 2a) and Cerro Mocho (Pampa del Salado thrust; Figure 2b) but still blind. Others argue that the main crustal thrust was the west verging Andacollo Loncopué Fault System (ALFS) under the western side of the Cordillera del Viento and the Cerro Moncol [Zapata et al., 1999; Cobbold and Rossello, 2003; Cobbold et al., 2008] (Figures 1 and 2). Thin skinned deformations in the Agrio fold-and-thrust belt were limited to the east by the Cerro Mula-Naunauco (CoMN in Figure 2b [Zapata et al., 2003]). Aptian to Cenomanian synorogenic deposits (Rayoso and Neuquén groups, Figure 3) in the foreland mark this event [Zapata et al., 2003; Cobbold and Rossello, 2003]. Cobbold and Rossello [2003] and Mosquera and Ramos [2006] invoked a foreland bulge in the Late Cretaceous to explain the thinning of these strata above the Chihuidos anticlines (Figures 1 and $2 b$ ).

[11] During the Paleocene to early Eocene, the Incaic phase was characterized by a rapid oblique convergence that provoked a dextral transpressive state of stress [Pardo-Casas and Molnar, 1987; Cobbold et al., 1999; Cobbold and Rossello, 2003]. The western limb of the Cordillera del Viento (ALFS) was activated and an Eocene phase of tectonic and magmatic activity occurred in the outer Agrio fold-and-thrust belt (Figure 2a) [Llambias and Rapela, 1989; Cobbold and Rossello, 2003]. The thin-skinned deformation front overpassed the Cerro Pichi Mula anticline (CoPM in Figure 2b) [Zapata et al., 2003]).

[12] The early Oligocene-early Miocene was a period of slow convergence [Pardo-Casas and Molnar, 1987]. Slab roll-back caused the subduction zone to steepen. Jordan et al. [2001], Ramos and Folguera [1999], Charrier et al. [2005], and Kay and Copeland [2006] argued that this period was marked by crustal extension while others considered that it was merely a period of tectonic quiescence [Cobbold and Rossello, 2003]. However, Cobbold et al. [2008] have since postulated that the western edge of the Neuquén Basin was undergoing shortening.

[13] The Quechua phase started after the rupture of the Farallon plate, 24 Ma ago. Convergence velocity increased and became more frontal at the trench [Cande and Leslie, 1986; Pardo-Casas and Molnar, 1987]. At the same time, the westward velocity of the South American plate may have been increasing for $30 \mathrm{Ma}$ [Silver et al., 1998]. This plate reorganization resulted in slab shallowing and in the compressive Quechua episode (early Miocene to present [Steinmann, 1929; Ramos et al., 1996]). During the early middle Miocene, the orogenic crustal front propagated to the east. North of the Cortaderas Lineament, the Tromen thrust cut through the thin-skinned Chos Malal fold-and-thrust belt [Viñes, 1990; Marques and Cobbold, 2002; Cobbold and Rossello, 2003; Galland et al., 2007b; Folguera et al., 2007a] (Figures 1 and 2a). Farther east, the Pampa Tril blind thrust folded the Huantraico syncline [Viñes, 1990; Cobbold and Rossello, 2003] (Figures 1 and 2a). In the inner domain, both limbs of the Cordillera del Viento were also reactivated [Folguera et al., 2007a]. South of the Cortaderas Lineament, the crustal front propagated to the Agua Amarga thrust which cut through the Cretaceous-Eocene thinskinned structures of the Agrio fold-and-thrust belt [Zapata et al., 2003; Zamora Valcarce et al., 2007] (Figures 1 and 2b). Farther east, crustal normal faults beneath the Chihuidos High were reactivated [Mosquera and Ramos, 2006].

[14] During the Plio-Quaternary, the convergence rate decreased [Pardo-Casas and Molnar, 1987]. This deceleration may have caused steepening of the Nazca plate [e.g., Kay, 2002], slab roll-back and back-arc extension [Ramos and Folguera, 2005; Folguera et al., 2007b, 2008]. In contrast, from recent structures and landforms, Cobbold and Rossello [2003] and Galland et al. [2007b] have suggested that compression is still ongoing. That is compatible with the current stress field where the greatest compressive stress is horizontal and trends broadly east-west in the area [Guzmán et al., 2007]. In the following chapters, we study geomorphological markers of the regional tectonic activity to infer the Plio-Quaternary tectonic context of this area.

\section{Remnant Terraces of the Neuquén River}

\subsection{Methodology and Data}

[15] We mapped and correlated the Plio-Quaternary deposits of the study area from multispectral optical satellite images, digital elevation models (DEMs) and geological maps (Figure 4) [Zöllner and Amos, 1973; Ramos, 1981; Ferrer, 1982; Leanza and Hugo, 1999]. We used the spectral radiance and texture on a red-green-blue (RGB) color combination of optical images to map lithological units. This approach was based on the use of Advanced Spaceborne Thermal Emission and Reflection Radiometer (ASTER) [Kahle et al., 1991] and Landsat 7 [Markham et al., 1997] images with a spatial resolution of 15 and $30 \mathrm{~m}$, respectively. We controlled the lithology in the field. Spatial correlation of the deposits was improved on the basis of their average topographic elevation.

[16] Topographic data were obtained from DEMs and measurements. DEMs are computed from Shuttle Radar Topographic Mission data (SRTM DEM), with a spatial resolution of $90 \mathrm{~m}$ and vertical precision of 10-16 m [e.g., Farr et al., 2007] and from stereo pairs of ASTER images (ASTER GDEM, spatial resolution of $30 \mathrm{~m}$ and vertical precision of 7-14 m, a product of METI and NASA). With the help of a differential Global Positioning System (DGPS), we were able to plot an accurate topographic profile. Spatial resolution is $5 \mathrm{~cm}$ and vertical precision is better than $10 \mathrm{~cm}$, which is in the same order of magnitude as the natural roughness of terrace treads.

[17] The regional longitudinal profile of the Neuquén River and its terraces (Figure 5) is based on the SRTM DEM. ASTER GDEM was used to plot profiles $10-30 \mathrm{~km}$ long (Figure 10) and DGPS for smaller features $(<5 \mathrm{~km}$ 


\section{A- Projection of terrace elevations Crest}

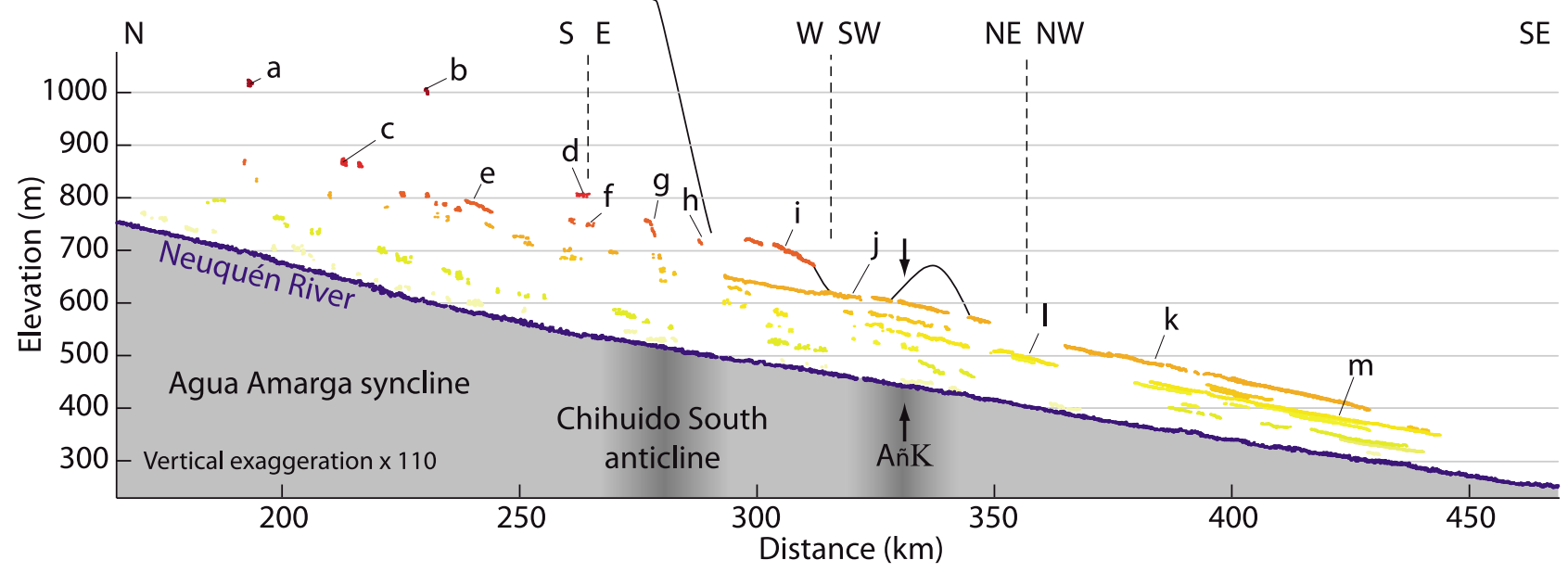

\section{B- Interpreted longitudinal profiles of terraces}

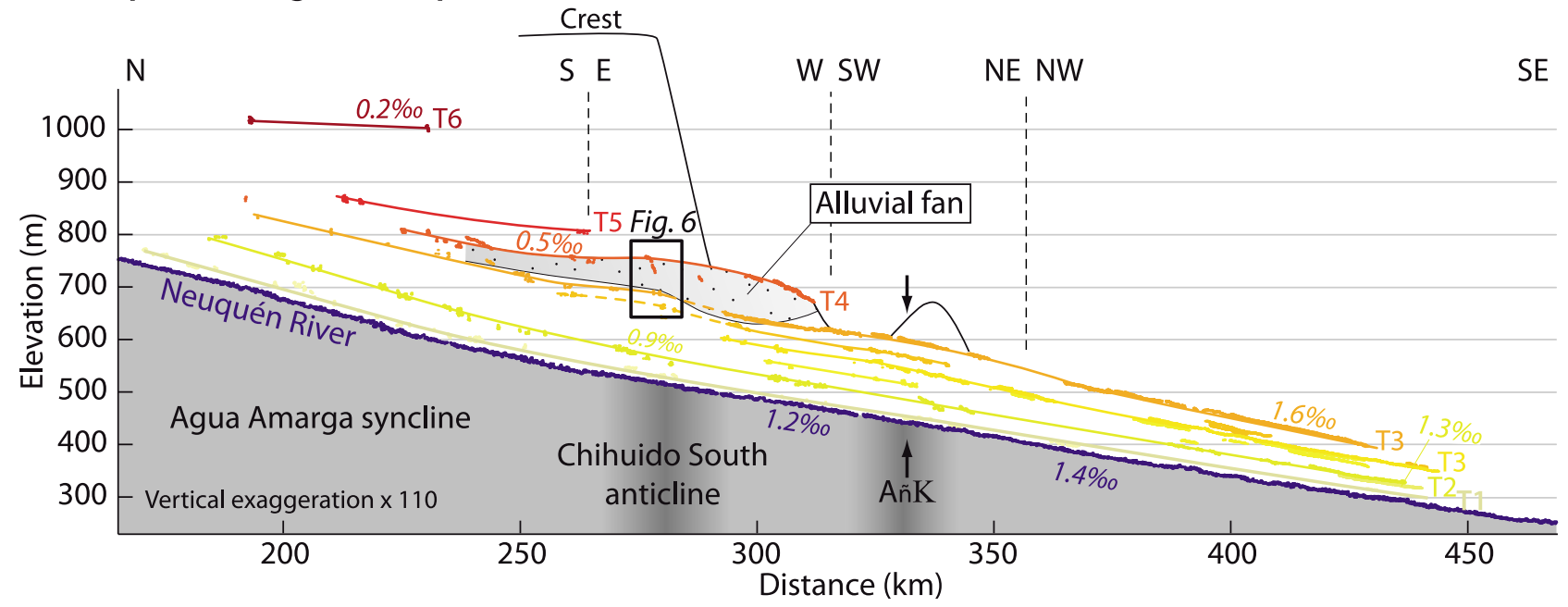

Figure 5. Longitudinal profile of the Neuquén River (blue line) and its remnant terraces (yellowish to reddish color bar) from the Pampa de Agua Amarga to Añelo. (a) Dots show the projection of the mean elevation of the remnant terraces mapped in Figure 4, and (b) lines the longitudinal profile interpolations. Black dots show the elevation of the crest. Letters a to $m$ refer to the remnant terraces mapped in Figure 4. Black arrows point out the Añelo knickpoint (AñK). The grey area with dots in Figure 5b shows the thickness of T4.

long) such as the remnant terraces in Figure 6 and an alluvial fan in Figure 8 .

\subsection{Arrangement of the Remnant Terraces}

[18] Quaternary deposits are well preserved in the area (Figure 4). We have identified six main terraces labeled T6 (the oldest and highest) to T1 (the youngest). T0 is the current alluvial plain.

[19] Remnant terraces are stepped and stand above the Neuquén Group (Cenomanian, Figure 3). Remnants of T6 are sparse in the Agua Amarga depocenter and missing east of the Chihuido South anticline. They are formed by a $50 \mathrm{~m}$ thick accumulation of 10-20 cm long pebbles of volcanic and basement rocks. A few isolated remnants of T6 culmi- nate at an elevation of $\sim 1000-1050 \mathrm{~m}, 350 \mathrm{~m}$ above the river bed. T5 remnants are also preserved, only in the Agua Amarga syncline, where they stand at an elevation of 850$900 \mathrm{~m}$. They are made of volcanic and quartzitic pebbles $(<10 \mathrm{~cm})$ in an accumulation around $60 \mathrm{~m}$ thick, superimposed over thinner levels of alluvial plain and breccias indurated by a silicic matrix. T4, at an elevation of 680$800 \mathrm{~m}$, shapes the Pampa de Agua Amarga upstream of the Chihuido South anticline with deposits roughly $40 \mathrm{~m}$ thick. East of the anticline, T4 deposits thicken to more than $140 \mathrm{~m}$. They are composed of $0.5-3 \mathrm{~m}$ blocks of Neuquén Group sandstones interbedded in volcanic and quartzitic pebbles at the base. These deposits form an alluvial fan which develops downstream from the apex of the Chihuido South anticline, over an area $25 \mathrm{~km}$ long and $15 \mathrm{~km}$ wide (Figure 4). Levels T3 

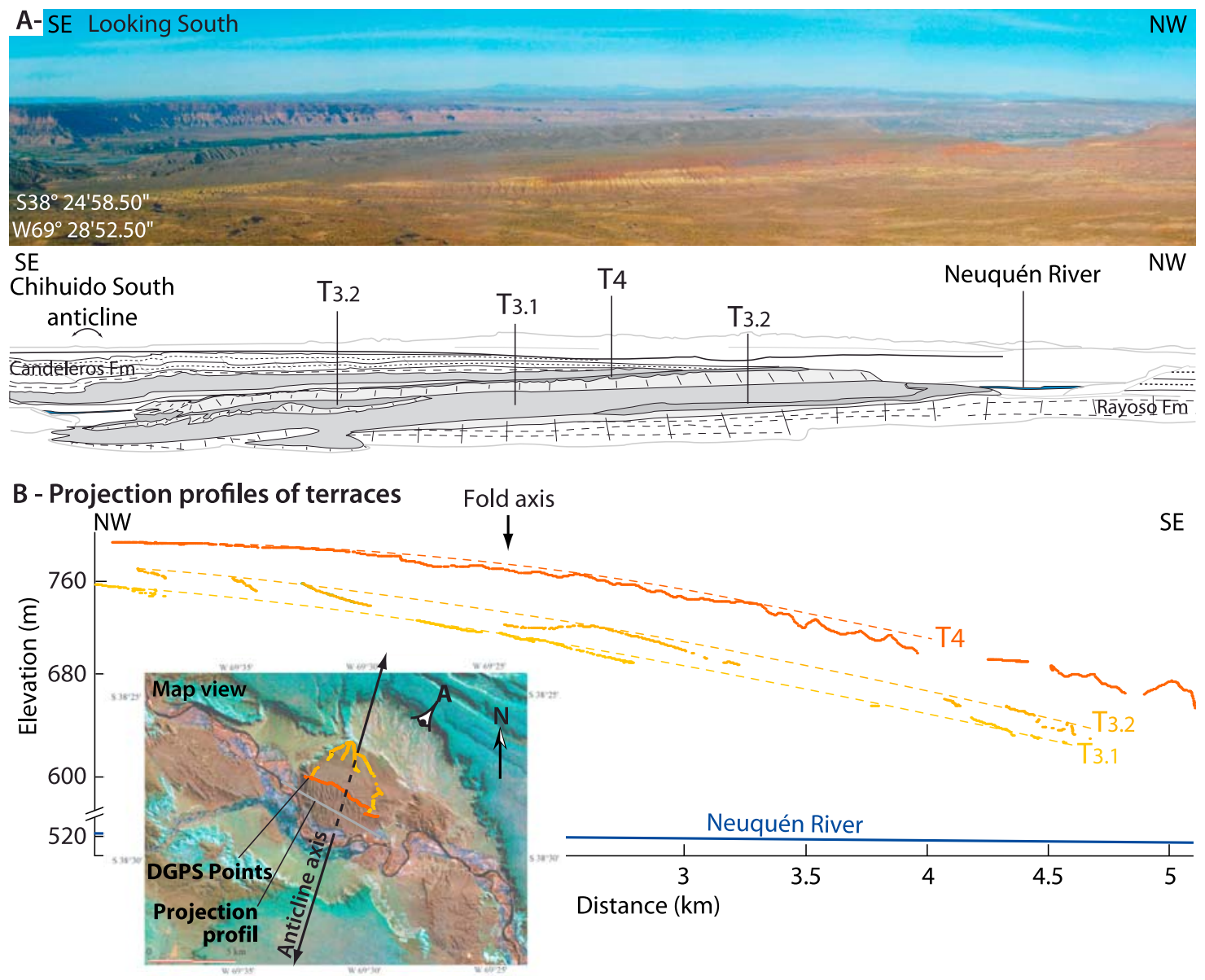

Figure 6. Tilting of the T3-T4 remnant terraces of the Neuquén River above the Chihuido South structure. (a) Field view (looking south) with interpretation of remnant terraces T4 and two subsidiary levels in T3 (labeled $\mathrm{T}_{3.1}$ to $\mathrm{T}_{3.2}$ ). (b) Topographic profiles across remnant terraces plotted from differential Global Positioning System (DGPS) data. Inset is a map of the DGPS leveled points (dots) with projection line. Figure $6 \mathrm{~b}$ is looking north; $\mathrm{SE}$ is on the right. Location is indicated in Figures 4 and 5.

to $\mathrm{T} 1$ are well preserved from erosion and follow the Neuquén River within a narrow valley that widens in the Añelo area. They are only 5 to $10 \mathrm{~m}$ thick and are made of basaltic, andesitic, and quartzitic pebbles $(<20 \mathrm{~cm})$. Their elevation ranges between 260 and $750 \mathrm{~m}$ (Figure 4).

[20] Judging from their thickness and location, these are probably two sets of terraces, the T6-T4 and the T3-T1 intervals. We found no T4-T6 terraces east of Añelo. T6-T4 interval determines two thick depocenters on either side of the anticline. T1-T3 deposits are thinner and more regular in thickness. The corresponding alluvial plains widen downstream of Añelo.

[21] Absolute dating of these remnant terraces is not yet available, but Ferrer [1982] and Leanza and Hugo [1999] ascribe the T4-T6 interval to the middle Pleistocene-late Pliocene. In the Chos Malal area, $\mathrm{K}-\mathrm{Ar}$ dating of a basaltic pebble in the T5 level yields an age of $1.4 \mathrm{Ma}\left(\mathrm{S} 34^{\circ} 22^{\prime} 10\right.$, W70 $\left.15^{\prime} 14\right)(H$. Freije, Total Austral, personal communication, 2009), demonstrating that $\mathrm{T} 5$ is Pleistocene or younger. Leanza and Hugo [1999] attributed T1 to T3 to the middle-late Pleistocene.

\section{Plio-Quaternary Folding of the Remnant Terraces}

[22] Figure 5 shows the longitudinal profile of the Neuquén River and its remnant terraces from the Agua Amarga syncline to Añelo, orthogonally projected along a segmented line that roughly follows the present-day river course (black dashed line in Figure 4). The $\mathrm{x}$ axis in Figure 5 refers to the distance from the source. For a given level, we consider the nearest remnant from the river bed and discard any likely to belong to an other course. The current river slope appears larger in the Agua Amarga syncline (Figures 4 and 5). In fact, a curvilinear projection along the present-day river course shows that this larger slope results from a projection artefact due to the meandering course of the river in the syncline. This same artefact may also affect the T1-T2 


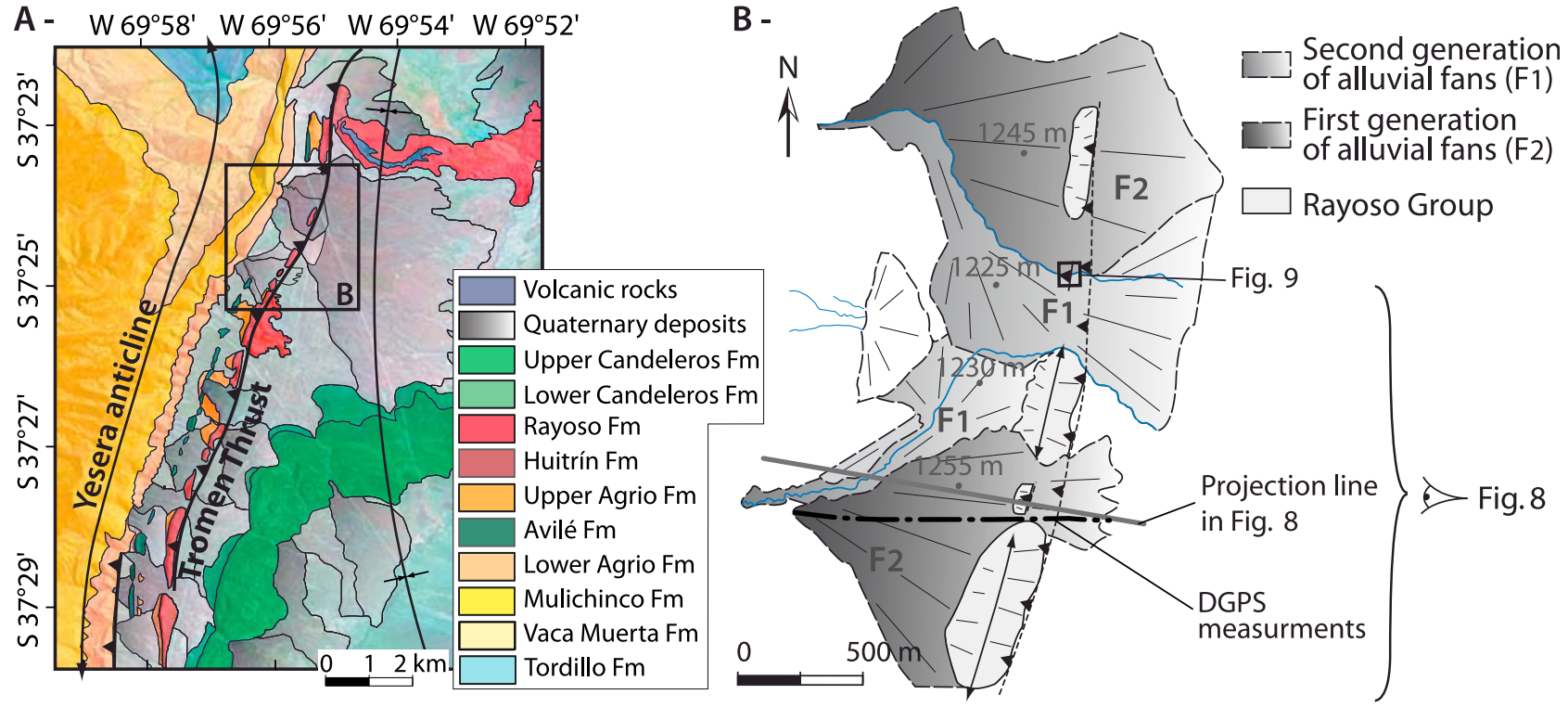

Figure 7. (a) Geologic map of the Yesera Front. Location is indicated by box in Figure 4. (b) Sketch map view of alluvial fans across the Tromen thrust $\left(F_{1}\right.$ and $\left.F_{2}\right)$. Location is indicated in Figure 7 . Dashed lines are the profiles in Figure 8; box is location of Figure 1. DGPS, differential Global Positioning System.

levels which are more or less parallel to the current course. Elevation of the river bed decreases from 700 to $250 \mathrm{~m}$ over a distance of $350 \mathrm{~km}$ resulting in a mean river slope of $1.3 \%$.

[23] The longitudinal profiles of the remnant terraces appear bulge-shaped across the Chihuido South-Añelo area. Upstream of the Chihuido South anticline, the slope of terraces decreases with age from around $0.9 \%$ in $\mathrm{T} 2$ to $0.5 \%$ in T4 and possibly $0.2 \%$ in the oldest level T6 (Figure 5). Conversely, downstream of Añelo, the slope increases from $1.3 \%$ for $\mathrm{T} 2$ to $1.6 \%$ for $\mathrm{T} 3$. The older the remnant, the more steeply the slope dips.

[24] A more detailed examination of the terrace longitudinal profiles reveals two distinct bulges. The westernmost located above the Chihuido South (Figure 5) is clearly marked in the T3-T6 levels. Locally at the apex of the Chihuido South, an embanked paleomeander of the Neuquén River shows alluvial deposits ascribed to T3 and T4 (Figure 4). We distinguish two subsidiary levels in T3, labeled $\mathrm{T}_{3.1}-\mathrm{T}_{3.2}$ (Figure 6). They are stepped in marly deposits of the Rayoso Formation (Aptian, Figure 3). Their elevations range from 650 to $760 \mathrm{~m} . \mathrm{T}_{3.1}$ is the floor of a $200 \mathrm{~m}$ wide paleovalley of the Neuquén River (Figure 6a). These three terraces dip steeply to the east, from $54.1 \%$ to $41.9 \%$, much more than the present-day slope of the Neuquén River $(\sim 1.3 \%$ o, Figure $6 \mathrm{~b})$. They flatten out to the west above the hinge of the anticline and hence appear slightly bent. Below $\mathrm{T}_{3.1}, \mathrm{~T} 1-\mathrm{T} 2$ terraces appear less bent at this location. The bending amplitude is difficult to quantify because the eastern end of T4 appears partially eroded. Nevertheless, the three terraces remain more or less parallel, which attests their subsequent folding.

[25] The eastern bulge is shown by an inflection in T2 and $\mathrm{T} 3,30 \mathrm{~km}$ east of the Chihuido South anticline $(\mathrm{x}=340 \mathrm{~km}$ in Figure 5). It correlates with a change in slope of the current Neuquén River. The river slope increases from 1.2\%o upstream of the inflection point to $1.4 \%$ downstream. Three other knickpoints also affect the Neuquén River longitudinal profile near Andacollo (Figure 1), Chos Malal and Neuquén City but they match the three main confluences of the Naheuve, Curileuvú and Limay rivers. They can be explained by an increased water discharge. The Añelo knickpoint (AñK in Figures 4 and 5), in contrast, does not correspond to any confluence and might result from climatic and/or tectonic factor. The fact that this knickpoint is located close to changes in terraces slopes suggests it results from a tectonic uplift located near Añelo.

[26] So the remnant terraces of the Neuquén River show two bulges (Figure 5). The westernmost, located above the Chihuido South, attests to an activity of the anticline during the T3-T6 interval, i.e., in the late Pliocene to middle Pleistocene. Farther east, the Añelo bulge is younger (T0 T3 interval) suggesting that uplift shifted eastward. Correlated with a NNE trending topographic high where sandstones of the Neuquén Group crop out (Figures 2, 4, and 5), this bulge might depict the present-day growth of a structure labeled Añelo anticline in Figure 4.

\section{Reactivation of the Tromen thrust}

[27] The Yesera anticline extends over $40 \mathrm{~km}$ from Chos Malal to the west to the Pampa Tril to the east (Figure 2a). Its forelimb is bounded to the east by the west dipping thickskinned Tromen thrust. Discontinuous north-south arcuate scarps, a few hundred meters long and more or less $30 \mathrm{~m}$ high, underline the topographic front. Scarps are observed over $10 \mathrm{~km}$ between the Neuquén River and the Cortaderas Lineament (Figure 7). In the central part of the Tromen 

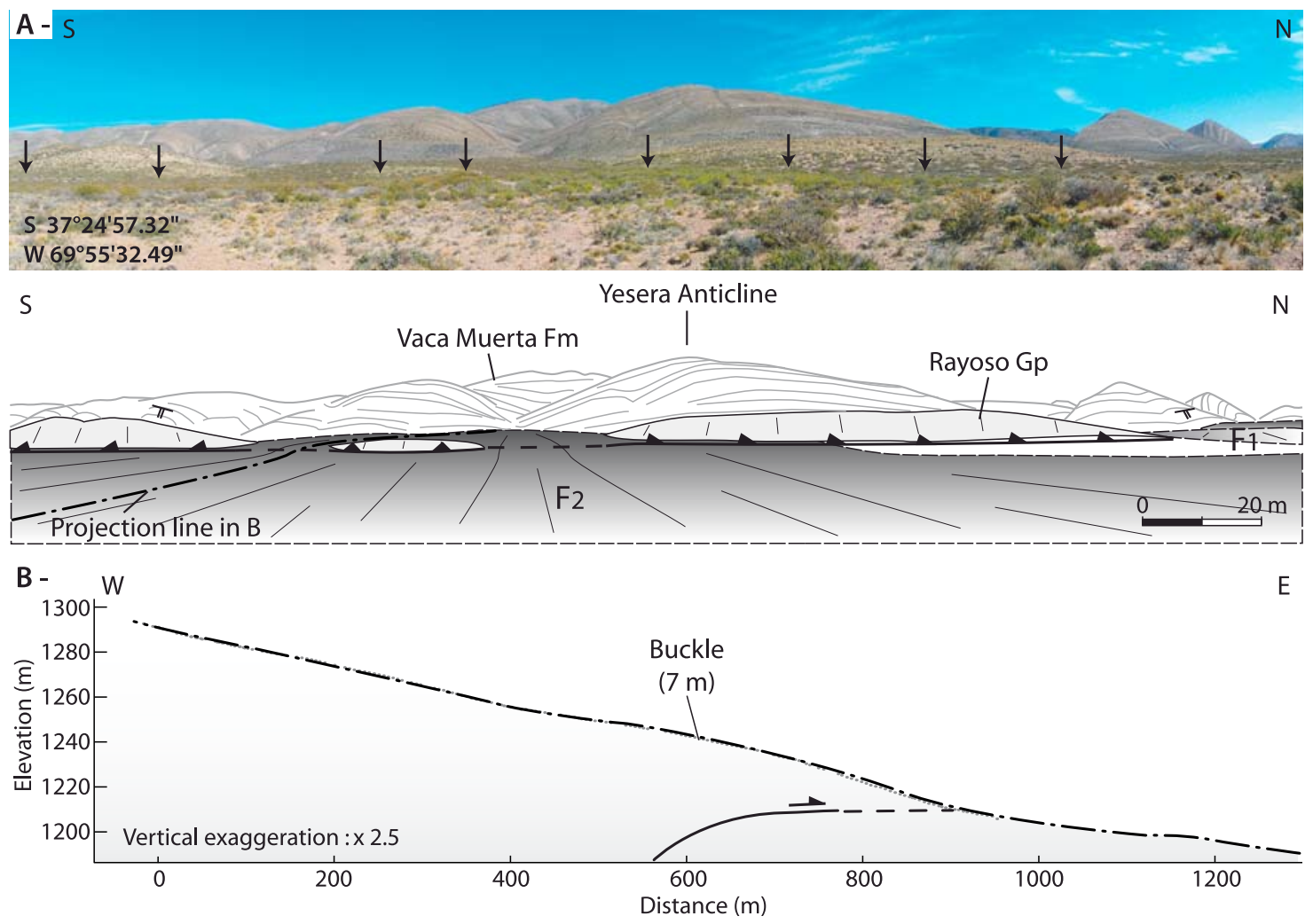

Figure 8. Folding of alluvial fans at the toe of the Tromen thrust. (a) Field view and interpretation of the bent fan $\left(\mathrm{F}_{2}\right)$. Black arrows point out the scarplet at the toe of the topographic front. (b) Topographic profiles across fan $F_{2}$ (DGPS data, location is indicated in Figures 7 and 8a).

thrust, one of these scarps involves the Rayoso Group (Lower Cretaceous) and slope deposits (Figure 8). Quaternary alluvial fans, $\sim 1 \mathrm{~km}$ long, extend to the toe of the mountain front (Figure 7). A first generation of fans (F2 in Figure 7) stretches around these scarps and overlaps them locally. A younger generation, with a lower average topographic elevation (F1 in Figure 7), has imbricated F2 and is incised by current rivulets. Scarplets in continuity with the main scarps, occasionally cut through the middle of two F2 fans (Figures 7 and 8a). DGPS leveling of the southern F2 fan shows it to be warped with an amplitude of $7 \mathrm{~m}$ (Figure $8 \mathrm{~b}$ ). The fault trace is lobate and convex toward the footwall suggesting the fault flattens out below the surface. This fault disrupts the F1 fan 500 meters to the north in a natural excavation along a rivulet (Figure 9). The bedrock overrides its debris slope deposits along a steep west dipping linear contact. This is accompanied by folding of the deposit in the footwall and by a reorientation of pebbles near the contact (Figure 9). We did not see a sharp fault plane or any striations. Nevertheless we suspect that there might be a reverse fault. Because its dip is strong and parallel to the strata, we infer bench-to-bench faulting. That could be related to a major fault at depth which is responsible of the main scarp.

[28] At the same latitude to the west, the backlimb of the Yesera anticline extends over $30 \mathrm{~km}$ in an area comprising the Tromen volcano, the La Amarga Trough and the Tromen volcanic plateau (Figures 2a and 10a). The latter is $5 \mathrm{~km}$ wide and limited at its western and southern boundaries by the Curileuvú and Neuquén rivers, respectively. Its average topographic elevation ranges from $1100 \mathrm{~m}$ in Chos Malal to $1350 \mathrm{~m}$ at the toe of Loma Alta Tilhué (Figure 10). Zöllner and Amos [1973] argue that the Tromen volcanic plateau was brought about by glacial erosion and deposition of glacial drift. Near Chos Malal however, channels of coarse sandstone and conglomerate made of basaltic pebbles 10 $20 \mathrm{~cm}$ long, point rather to a fluvial environment. A volcanodetritic breccia of decimetric to metric boulders sparsely overlaps these deposits. A similar conglomerate caps the Cerro de la Virgen, west of Chos Malal (Figure 10). These alluvial deposits are the highest of the Chos Malal fold-andthrust belts and we ascribe them to T6, a former widespread alluvial plain. As the drainage network has to flow eastward, these alluvial terraces should also slope to the east. T6 above the Cerro de la Virgen slopes gently to the east but dips steeply to the west $(52.4 \%$ ) above the Tromen volcanic plateau (Figure 10b). We conclude that the plateau has been west tilted resulting in an uplift of $\sim 300 \mathrm{~m}$ at Loma Alta Tilhué. The tilted area is $7 \mathrm{~km}$ wide, suggesting that the total wavelength of the deformed area is much wider and should overpass the usual wavelength of thin-skinned structures in the Chos Malal fold-and-thrust belt. In addition, the tilted area coincides with the westernmost end of the Yesera anticline backlimb, clearly imaged in seismic sections (Figure 10b) [Kozlowski et al., 1996]. We therefore infer 

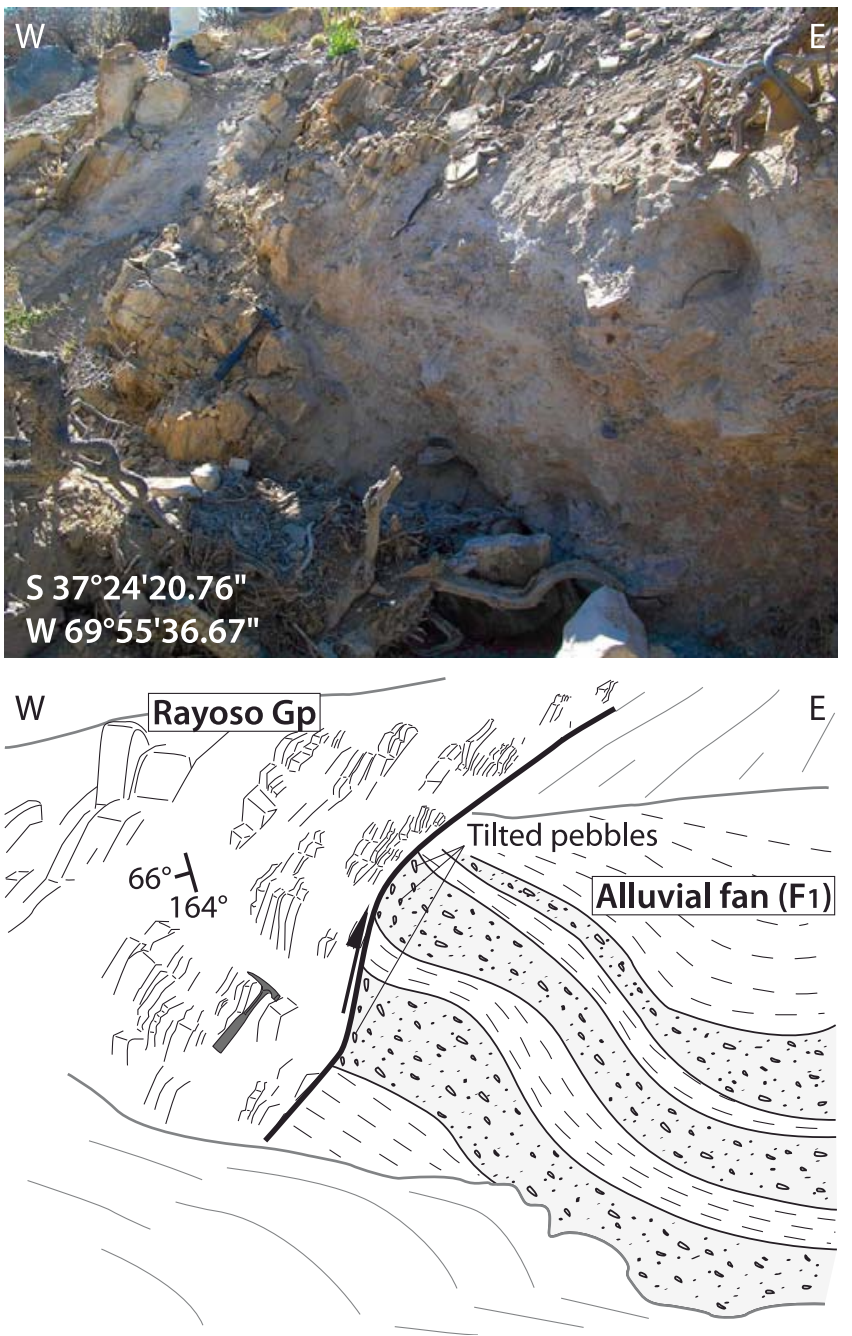

Figure 9. Reverse fault across the younger fan $F_{1}$ exposed in a natural excavation at the toe of the Yesera Thrust. The Rayoso Group overrides its debris slope deposits. Location in Figure 7. The polygonal grey overlay represents the fault plane.

from this that the tilt may result from the activity of the crustal Tromen thrust.

[29] Faults cutting across alluvial fans and the back tilt of the Tromen volcanic plateau attest of the Plio-Quaternary reactivation of the Yesera anticline. We postulate that the $40 \mathrm{~km}$ wide deformed area is crustal in origin and coincides with the crustal deformation front of the mid-Miocene times. This post-T6 tectonic activity testifies to Plio-Quaternary compression.

\section{Reactivation of the Thin-Skinned Agrio Fold-and-Thrust Belt}

[30] The Cerro Negro anticline is located in the southern termination of the thick-skinned Agua Amarga syncline at the toe of the Agua Amarga thrust (Figure 4). Structurally, it belongs to the thin-skinned tectonic wedge of the Agrio fold-and-thrust belt; $25 \mathrm{~km}$ long and $12 \mathrm{~km}$ wide, it trends north-south and is made of sandstone and marl of the Neuquén Group (Cenomanian, Figure 11). Its underlying ramp originates in the Auquilco evaporites (Figure 3). The Agrio river currently flows through the anticline (Figure 11).

[31] Alluvial deposits nested above the geological bedrock overlap the anticline (Figures 11 and 12a). They are part of the large surfaces extending tens of square kilometers which are the remnants of an alluvial plain fed by the Neuquén and Agrio rivers and by other rivers arriving from the southwest. These levels laterally correlate to the T4-T5 terraces of the Neuquén River (Figure 11). They are partly eroded at the apex of the anticline (Figures 11 and 12a).

[32] We have measured the height of the alluvium base and its thickness in six places along the southern end of the anticline (Figures 11 and 12a) and plotted the measurements on an $\mathrm{E}-\mathrm{W}$ profile showing spatial variations in T5 (Figure 12b). The alluvium base lies at an elevation of $850 \mathrm{~m}$ at the eastern and western toes of the anticline whereas it stands $160 \mathrm{~m}$ higher at the apex (Figures 12a and 12b). That suggests reactivation of the anticline following deposition of T5. Moreover, T5 alluvium thickness is reduced to a few meters $(<10 \mathrm{~m})$ of pellicular blanket at the apex of the anticline, while it reaches 25 to $70 \mathrm{~m}$ on both sides of the structure (Figure 12b). On the eastern limb of the anticline, the alluvium base slopes $10^{\circ}$ to the east whereas an intermediary layer dips $4^{\circ}$ and the uppermost one only $2^{\circ}$ to the east (Figure 12c). This progressive unconformity attests to a syndeposition tilting of the alluvium. T4 is also slightly bent above the northern end of the anticline and its thickness also decreases at the apex, an indication that folding was still ongoing during its deposition.

[33] In their structural context, these observations shows that the thin-skinned wedge of the Cretaceous and Miocene Agrio fold-and-thrust belt was reactivated during the deposition of T5 and T4 (Pleistocene).

\section{Discussion}

\subsection{Plio-Quaternary Compression in the Southern Neuquén Basin}

\subsubsection{Uplift of the Foothills}

[34] The longitudinal profile of the Neuquén River and its Plio-Quaternary remnant terraces has two bulges at the toe of the orogenic front.

[35] The westernmost bulge is located above the Chihuido South anticline (Figure 5) and appeared during deposition of T3-T6, i.e., in the late Pliocene-middle Pleistocene. It is well preserved in remnants of the T4 that are continuous across the anticline. The T4 valley-parallel profiles show a bulge $\sim 100 \mathrm{~km}$ wide with an amplitude of $35 \mathrm{~m}$.

[36] At the orogen margins, high rates of uplift disturb mass transfer from the orogen interiors to the foreland [e.g., Humphrey and Konrad, 2000; Sobel et al., 2003]. Bedrock uplift across flow passes causes deposition immediately upstream of the uplift, which distorts the river's longitudinal profile. West of the Chihuidos, a thickening of the alluvial deposits correlates to the widening of the alluvial plain (T4-T6, Figure 4) and weaker terrace slopes (Figure 5). 

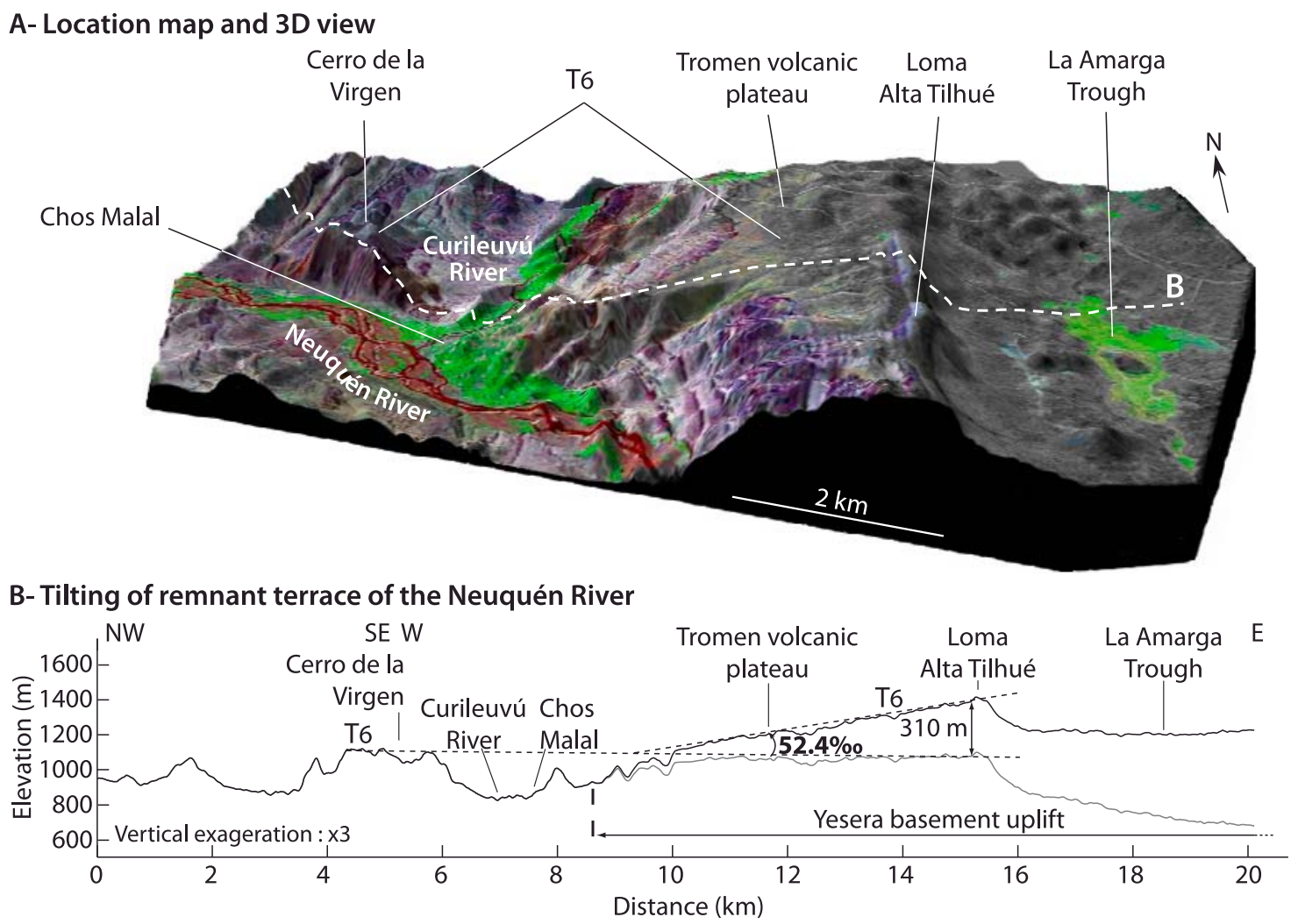

Figure 10. Tilting of remnant terraces of the Neuquén River in the western limb of the Yesera front. (a) Three-dimensional view of the Yesera backlimb. (b) Topographic profiles of the T6 remnant terraces before (grey) and after (black) a tilting of 52.4. Location is indicated in Figure 1.

This suggests that sediments were stored in the Agua Amarga syncline in response to the uplift of the Chihuido South anticline. On the eastern limb of the bulge, the uplift was responsible for the deposition of a large, steeper alluvial fan apron (T4) at the catchment outlet.

[37] We contend that the bulge shape marked in T4-T6 terraces above the Chihuido South anticline stems from Plio-Quaternary activity of the anticline. This shape is not, however, purely tectonic and results from the morphological response of this uplift. The response was an attempt to balance the local tectonic perturbation and thereby achieve a new equilibrium profile. The river needs to adjust its local slope by deposition or erosion, taking into account the stream power, sediment flux, bedrock erodability, strain rate, etc. It should not be interpreted as the result of folding of an initially gently dipping surface. This explains why the bulge stretches over a hundred kilometers from the Tromen thrust to the west of Añelo, over a distance that overpasses the Chihuidos area. Moreover, the river's course is not orthogonal to the structure in its upper part. This makes it difficult to estimate the fold wavelength and amplitude from the analysis of valley-parallel terraces profiles. Remnant terraces show, at any rate, that the Chihuido South anticline was still growing during the deposition of T4.

[38] Uplift of the Chihuido South anticline is also marked in the abandoned paleomeander of the Neuquén River
(Figure 6). This paleovalley, corresponding to $\mathrm{T} 3$ and $\mathrm{T} 4$ terraces, acted as a passive marker of uplift. Its current slope, $\sim 50 \%$, results essentially from tectonic tilting, to judge from the much flatter slope of the river.

[39] The structural pattern of the Chihuidos anticlines, $150 \mathrm{~km}$ long and $30 \mathrm{~km}$ wide, shows that uplift results from a crustal-scale process. As shown by thickness variations of the Neuquén Group, this area was already a topographic high during the Cretaceous, and has been interpreted as the lithospheric bulge of the Chos Malal range [Cobbold and Rossello, 2003]. Mosquera and Ramos [2006] also invoke a tectonic inversion of Jurassic half grabens in Miocene times. Due to the age of the terraces, this crustal uplift was still ongoing during the late Pliocene-middle Pleistocene.

[40] The easternmost bulge is visible in the T1-T3 terraces and correlates with a knickpoint in the current river (T0) near Añelo (AñK in Figure 5). The river incises the Neuquén Group (Figure 3) at this point no lithologic contrast in the homogeneous Cretaceous sandstones can be invoked to explain the anomalies in the longitudinal river profile. The tectonic origin of this inflection is supported by the bending of T2 and T3 terraces (Figure 5). They show a $50 \mathrm{~km}$ wide anomaly located above the slope inflexion. This bulge also corresponds to a $100 \mathrm{~m}$ topographic high in which the Neuquén Group crops out. Its NNE trend and its length are similar to those of the Chihuidos anticline. This 


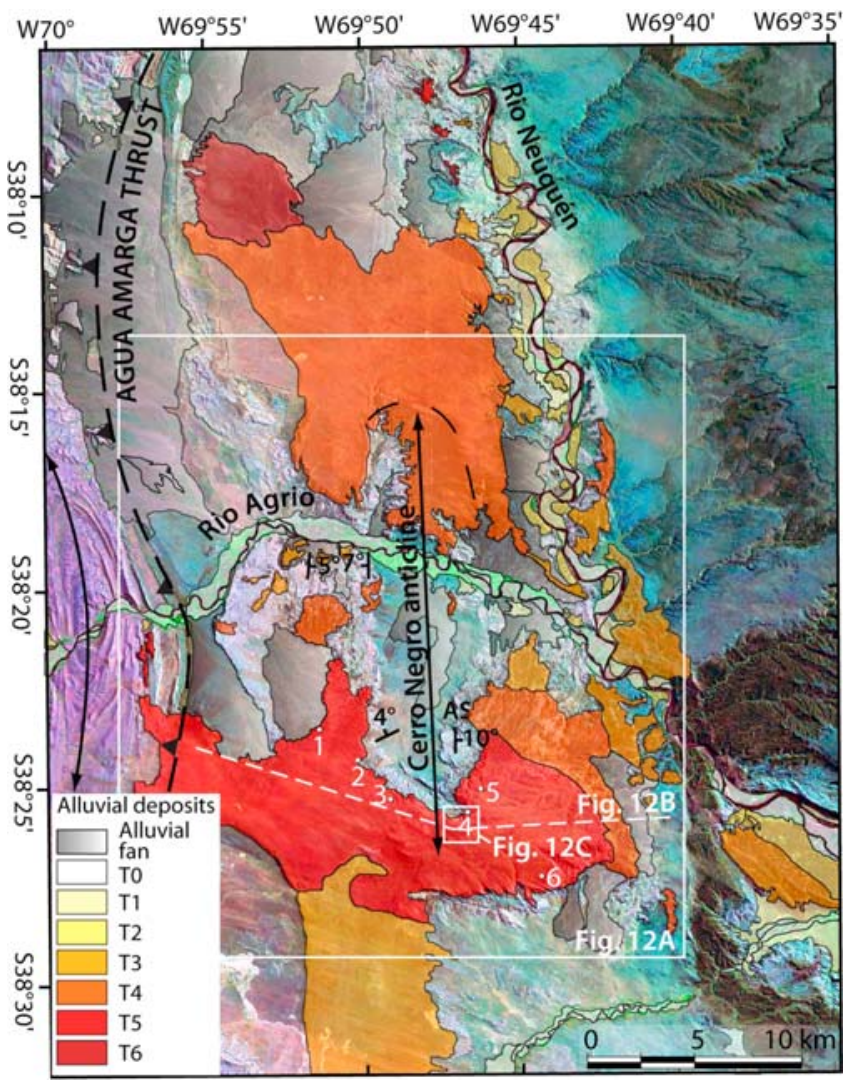

Figure 11. ASTER image of the Cerro Negro anticline and map of the Plio-Quaternary deposits in the Pampa de Agua Amarga (yellowish to reddish color bar). Location is indicated in Figure 4.

ridge may mark the growth of a new crustal-scale anticline located near Añelo, $30 \mathrm{~km}$ east of the Chihuido South anticline (Figure 4) which would be middle Pleistocene to Present in age. Note that it may also have bent the Neuquén River northward along its western limb (Figure 4).

\subsubsection{Propagation of the Andean Orogenic Front}

[41] Since the Cretaceous, the structural evolution of the area shows eastward propagations of the crustal orogenic front. As stated above, the latter was initially located under the inner domain of the fold-and-thrust belts during the late Cretaceous, but shifted to the Tromen and Agua Amarga thrusts during the Miocene and cut through the former thinskinned structures of the fold-and-thrust belts [Zapata et al., 2003; Zamora Valcarce et al., 2007] (Figures 1 and 2). Cobbold and Rossello [2003] have suggested that the thickskinned Agua Amarga thrust was already active during the Late Cretaceous. We show here that Plio-Quaternary uplifts are located farther to the east at the toe of the Miocene crustal front, beneath the Chihuidos and Añelo anticlines.

[42] The wavelength of the uplifted structures suggests that they are related to crustal-scale faults. To the north, the western limb of the Chihuido North anticline is steeper than the eastern one. This combination of asymmetry, wavelength of the uplifted area and proximity of the mountain front show that it is not a lithospheric bulge. The Chihuido
North anticline might show the forward propagation of a fore thrust as observed farther to the north in the Neuquén Basin [e.g., Viñes, 1990; Vergani et al., 1995; Kozlowski et al., 1996; Giambiagi et al., 2001, 2008]. Although surface observations do not allow to answer the question of the thrust vergence, this structure marks the migration to the east of the thick-skinned deformation front. In this setting, the Añelo uplift is the outer blind orogenic front.

[43] Our data also shows that the outward migration of the crustal orogenic front is accompanied by a reactivation of the former crustal thrusts. Reverse faulting and folding of Quaternary fans above the Tromen thrust indicate the reactivation of the Miocene orogenic front. This supports the observations of Marques and Cobbold [2002, 2006] and Galland et al. [2007a], suggesting a coeval Plio-Quaternary activity of the Tromen thrust and the volcano. Farther south, folding of the T4 and T5 terraces shows also that the Cerro Negro anticline has been reactivated recently. This anticline belongs to the thin-skinned Agrio fold-and-thrust belt and its reactivation may be related to the Pleistocene activity of the thick-skinned Agua Amarga thrust.

[44] Widening and thickening of the Andean orogenic wedge require a Plio-Quaternary compressive state of stress in the southern Neuquén Basin. Borehole breakouts analysis shows that the current horizontal stress direction $\left(\mathrm{SH}_{\max }\right)$ is $\mathrm{E}-\mathrm{W}$ in the foreland of the Neuquén Basin [Guzmán et al., 2007]. Coblentz and Richardson [1996] and Guzmán et al. [2007] argue that the first-order direction is controlled by forces resulting from the convergence of the Nazca and South American plates [Angermann et al., 1999; Norabuena et al., 1999; Kendrick et al., 2003] (azimuth $080^{\circ}$ ). In a second-order $S H_{\max }$ directions tend to be perpendicular to the thick-skinned structures (Figure 1) which would correspond to a basement structural control [e.g., Mosquera and Ramos, 2006] and a topographic stress control [Meijer et al., 1997; Marques and Cobbold, 2002, 2006]. This state of stress is compatible with ongoing regional compression and reactivation of thick-skinned structures. A regional uplift and a strong bedrock incision are supported by the oldest remnant terraces that are found several hundred meters above the current drainage network.

\subsection{Is There Any Plio-Quaternary Extension in the Southern Neuquén Basin?}

\subsubsection{Thin-Skinned Extension}

[45] North of the Cortaderas Lineament, some authors invoke a regional collapse of the area due to a current extensional state of stress [Ramos and Folguera, 2005; Ramos and Kay, 2006; Kay and Copeland, 2006; Folguera et al., 2007b, 2008]. According to Folguera et al. [2008], the La Amarga Trough in the hanging wall of the Yesera anticline, west of the Tromen and Wayle volcanoes, results from crustal extension (Figure 1). Morphologically, this trough is a $30 \mathrm{~km}$ long, NNE to NNW trending depression. From seismic data, Folguera et al. [2008] reveal important structural changes along a strike, which they interpret, in the north, as a set of extensional faults limiting basins approximately $10 \mathrm{~km}$ long and $1 \mathrm{~km}$ wide filled with syntectonic lavas of the Tromen and Wayle volcanoes (2-1.4 Ma in 
A- 3D view of the Cerro Negro anticline (Looking West)

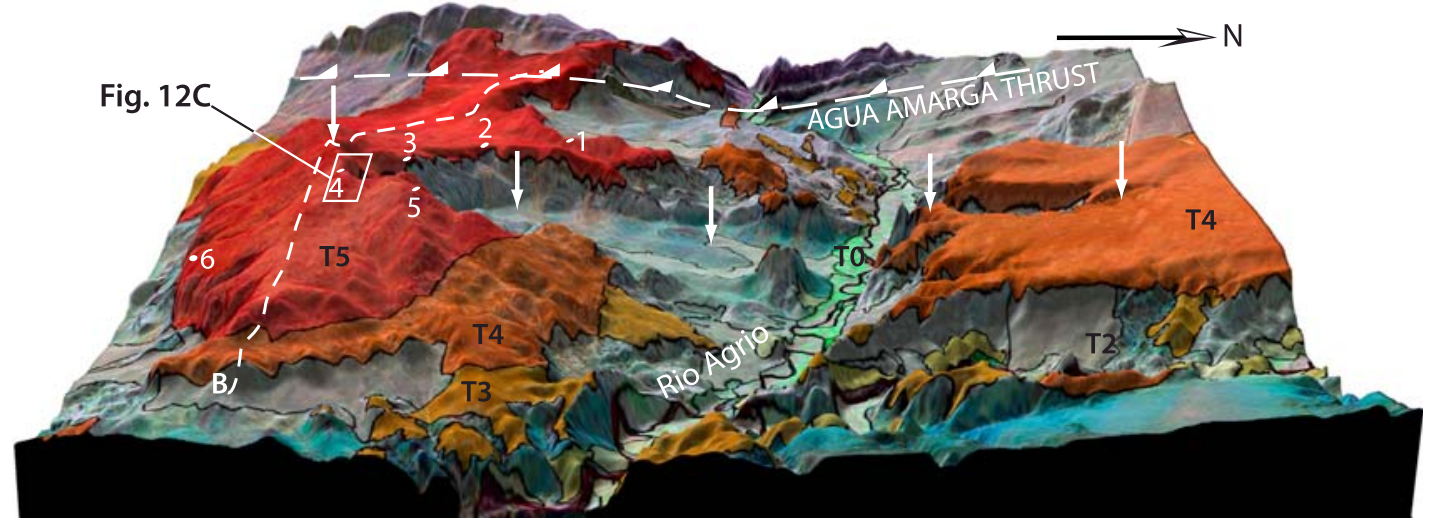

B- Topographic profile across the Cerro Negro anticline

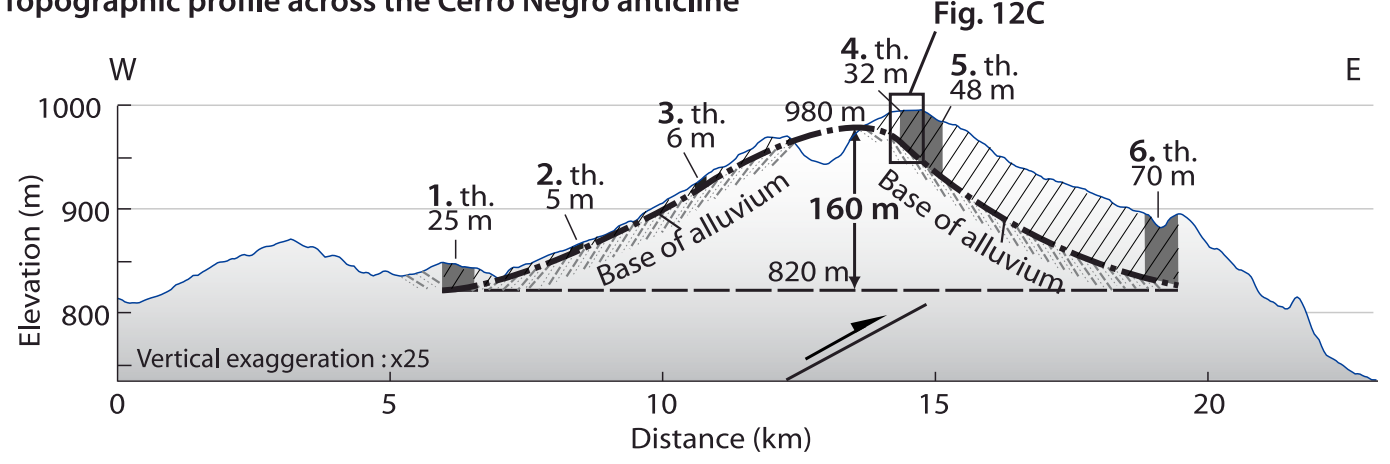

\section{C- Unconformity in aggraded alluvium at the apex of the Cerro Negro anticline}

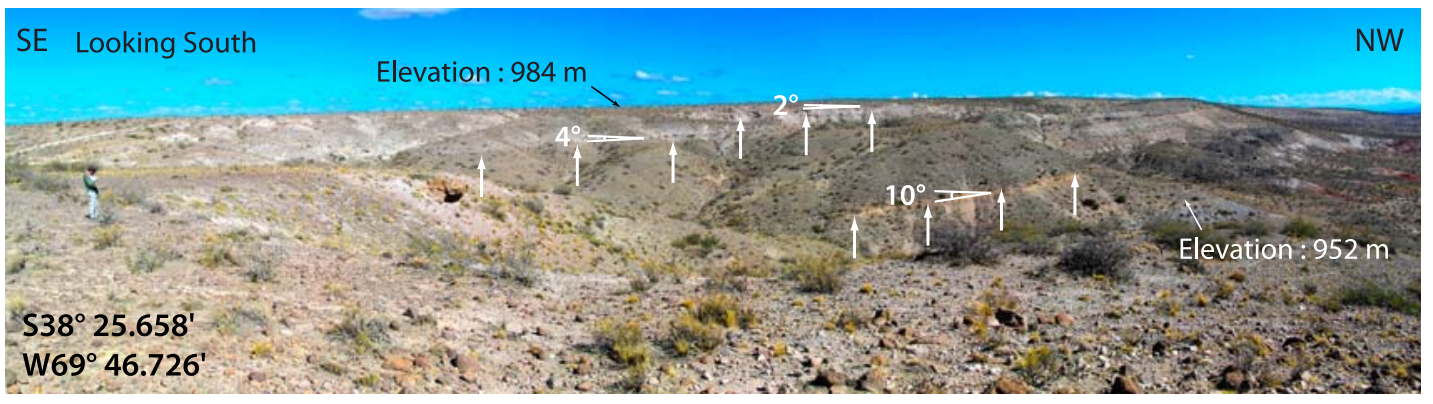

Figure 12. Reactivation of the thin-skinned Agrio fold-and-thrust belt. Folding of alluvial deposits above the Cerro Negro anticline in the Agua Amarga syncline. (a) Three-dimensional view (ASTER image and SRTM DEM) of the Cerro Negro anticline (looking west). The Plio-Quaternary map matches the relief (see Figure 11 for the legend colors and the location). White arrows point out the anticline axis. (b) Topographic profile across the Cerro Negro anticline showing the alluvium base (located in Figures 11 and 12a). Grey boxes show the thickness measured in the field. Numbers correspond to GPS field measurements located in Figures 11 and 12a. (c) Field view (looking south) of a progressive unconformity in three superimposed alluvial layers at the apex of the Cerro Negro anticline (located in Figures 11, 12a, and $12 \mathrm{~b}$ ). White arrows point out the bottom of the three layers. AS, apparent slope.

age). Farther south, Folguera et al. [2008] invoke an east verging listric fault which is responsible for a half graben $10 \mathrm{~km}$ long and $7 \mathrm{~km}$ wide filled with 30-60 m of volcanic deposits. The size of these structures nevertheless suggests a shallow rooting. According to fault scaling laws [e.g., Cowie and Scholz, 1992; Schlische et al., 1996], the displacement (D) at the fault center is linked to the fault length (L) by the relationship $\mathrm{D}=0.03 \mathrm{~L}^{1.06}$. Hence, the cumulative throw of the master faults probably does not exceed $340 \mathrm{~m}$. These faults probably originate in the shallow Auquilco evaporites (Oxfordian, Figure 3), and cause the collapse of part of the thin-skinned Chos Malal fold-and-thrust belt [Folguera et al., 2008]. Similar north-south valleys $10 \mathrm{~km}$ long and 200-300 m wide, are observed at the apex of the Chihuido 
North anticline (Figure 1). Nivière et al. [2007] describe roll-overs and turtle structures rooted $1000 \mathrm{~m}$ in depth in the Huitrín evaporites (Aptian, Figure 3). The master faults accommodate a maximum throw of $370 \mathrm{~m}$. Such structures are typical of salt tectonics. They have been described on passive margins as gravitational gliding down gentle slopes. We contend from the evidence that the growth of crustalscale compressive structures tilted the Auquilco and Huitrín evaporites and was responsible for gravitational extension above the orogenic fronts.

[46] Alternatively, Galland et al. [2007a] interpreted some tension fractures as being caused by the growth of the anticline over which the Tromen volcano is located. That results in a vertical major axis of the stress tensor at shallow depth, while deeper stress field remains compressive.

[47] It is clear that the Plio-Quaternary extensional features in the study area are much smaller in size than the compressive ones. The normal faults do not correlate with the inherited structures and all are thin skinned. This suggests that the state of stress remains compressive at the crustal scale. We postulate that these extensional features more probably originate in gravitational gliding above limbs of the orogenic fronts. They would be the consequence of the regional Plio-Quaternary uplift.

\subsubsection{Geodynamics, Magmatism, and State of Stress in} the Back Arc

[48] According to Ramos and Folguera [2005], Ramos and Kay [2006], Lara and Folguera [2006], and Folguera et al. [2007b, 2008], regional extension results from the geodynamic setting. At $4 \mathrm{Ma}$, back-arc volcanism with release of silicic or mafic magma has been active in the area (as in Tromen, Auca Mahuida and Payún volcanoes, and sparse minor events in the Chihuido North area [see Kay, 2002; Kay et al., 2006]. Folguera et al. [2008] consider that magmatic emplacement has been controlled by the formation of extensional basins such as that of the Las Loicas Trough. This volcanism is concomitant with a 500 to $300 \mathrm{~km}$ trenchward retreat of the volcanic arc which has been interpreted as resulting from the steepening of an initially subhorizontal slab [e.g., Kay, 2002; Ramos and Kay, 2006]. Such steepening would have driven an influx of asthenospheric mantle, causing melting and widespread back-arc volcanism, accompanied by crustal attenuation [Yuan et al., 2006; Folguera et al., 2007b] and collapse of the entire crust [e.g., Ramos and Kay, 2006; Folguera et al., 2007b, 2008]. South of the Cortaderas Lineament, extension would have been restricted to the volcanic arc in the main Cordillera and to the Loncopué Basin, 3-4 Ma ago (Figure 1) [Folguera et al., 2007b, 2008]. Recently, its generalization to the Chos Malal and Agrio fold-and-thrust belts would be concomitant with a narrowing of the volcanic arc and a minor slab steepening [Stern, 1989; Ramos and Kay, 2006; Lara and Folguera, 2006].

[49] However, Cobbold et al. [2008] and Galland et al. [2007a] hold that the path by which magmatic rocks reach the surface does not necessarily require extension. From analogue modeling, [Galland et al., 2007a] show that magma emplacement and rising can happen during horizontal shortening at depth. Cobbold and Rossello [2003], Cobbold et al. [2008], and Galland et al. [2007a] concluded that back-arc volcanism and regional compression could be coeval.

[50] The link among subduction, magma emplacement and the state of stress in the back arc is therefore not straightforward. It has been discussed in the scope of analogue and numerical modeling and of statistical analyzes of natural cases. Although laboratory experiments confirm that slab steepening favors a decrease of the overriding plate shortening, they show that shortening may continue through an episode of slab roll-back [Guillaume et al., 2009a]. Lallemand et al. [2005] noted that crustal back-arc extension is generally observed for slab dips steeper than $51^{\circ}$ and shortening for dips less than $31^{\circ}$. Farther north, for example, the Peruvian and northern Chilean trench is a $30^{\circ}$ dipping slab [Barazangi and Isacks, 1976]. It is linked to active folding and thrusting at the front of the Bolivian orocline [Horton and DeCelles, 1997]. Thus, steepening of the Nazca plate to only $30^{\circ}-35^{\circ}$ beneath the Neuquén Basin does not necessarily imply back-arc extension. Back-arc shortening is also correlated with the absolute motion of the overriding plate [Jarrard, 1986; Heuret and Lallemand, 2005; Heuret et al., 2007; Schellart, 2008]. According to Schellart [2008], extension prevails when trenchward motion of the overriding plate is slow compared to the trench retreat. This mainly occurs closer than $600 \mathrm{~km}$ from the lateral slab edge where mantle flows around the edge facilitate slab roll-back. Considering that the Neuquén Basin is located $1000 \mathrm{~km}$ north of the southern edge of the Nazca plate (Chile Ridge, Figure 1), the state of stress should be compressive. In addition, Schellart et al. [2008] compare trench and plate migration velocities for all the subduction zones on Earth. Many velocity models are calculated in different global plate tectonics reference frames. Each model shows that, in South America, trench retreat is slightly slower than the absolute trenchward motion of the overriding plate, leading to a compressional or at least neutral state of stress in the southern central Andes [Schellart et al., 2007]. Thus, the regional geodynamic settings are compatible with the ongoing E-W crustal shortening we have discussed for.

\section{Conclusions}

[51] We have made use of our observations of alluvial deposits of the Neuquén River and its tributaries as evidences for Pleistocene deformations. Along the mountain front, the topographic profile of the remnant terraces of the Neuquén River is bent above the southern end of the Chihuido South anticline. This shows that the anticline, initiated during the Cretaceous [Cobbold and Rossello, 2003], reactivated during the Miocene [Mosquera and Ramos, 2006] and was still ongoing during deposition of these terraces (late Pliocene-middle Pleistocene). East of the Chihuidos anticline, the bending of more recent terraces and the presence of a knickpoint in the current longitudinal profile of the river suggests the active growth of the Añelo anticline. This folding is concomitant with reactivation of the middle Miocene crustal orogenic front, indicated by surface faulting cutting alluvial fans above the fault trace of the Tromen thrust. In addition, the thin-skinned tectonic wedge of the Agrio fold-and-thrust belt also appears reac- 
tivated in the southern Agua Amarga syncline. These data suggest that the southern Neuquén basin is still shortening in response to a mainly compressional state of stress, and that the deformation front is propagating farther to the east.

[52] This compression is not compatible with the extensional state of stress invoked by Ramos and Folguera [2005], Ramos and Kay [2006], and Folguera et al. [2007b, 2008]. We interpret the normal faults and troughs observed at the apex of the Chihuido North anticline and along the western limb of the Yesera anticline as the consequence of a thinskinned gravitational gliding of the sedimentary cover. This would result from tilting due to the eastward propagation of the orogenic front and to reactivation of the thick-skinned Tromen thrust. So these extensional features are not thick skinned and should not be factored into characterization of the regional state of stress. We argue, in contrast, that compression has been maintained in the study area despite the steepening of the slab that has been ongoing for $4 \mathrm{Ma}$. In fact, statistical analyses of subduction zones [Heuret and Lallemand, 2005; Lallemand et al., 2005; Heuret et al., 2007; Schellart et al., 2007; Schellart, 2008] show that, effectively, slab steepening does not necessarily trigger an extensional state of stress in the overriding plate.

[53] Acknowledgments. Our thanks to Total for funding our project in the Neuquén Basin. We are grateful to Hugo Freije (Total Austral), who obtained $\mathrm{K}$-Ar ages on sample from terraces near Chos Malal, and to Peter Cobbold and the other reviewer who made a comprehensive review, which resulted in a better paper. Eventually, we thank Jacquie Wade (ANGLOFILE sarl), who provided a smooth and correct English writing.

\section{References}

Angermann, D., J. Klotz, and C. Reigber (1999), Spacegeodetic estimation of the Nazca-South America Eulervector, Earth Planet. Sci. Lett., 171, 329334, doi:10.1016/S0012-821X(99)00173-9.

Backé, G. (2006), Partitionnement de la déformation en zone de convergence: Le cas des Andes vénézuéliennes et du Bassin de Neuquén (Andes Centrales méridionales), Ph.D. thesis, Univ. of Pau, Pau, France.

Barazangi, M., and B. L. Isacks (1976), Spatial distribution of earthquakes and subduction of the Nazca Plate beneath South America, Geology, 4, 686692, doi:10.1130/0091-7613(1976)4<686: SDOEAS $>2.0 . \mathrm{CO} ; 2$.

Bracaccini, O. (1970), Rasgos tectónicos de las acumulaciones mesozoicas en las provincias de Mendoza y Neuquén, República Argentina, Asoc. Geol. Argent. Rev., 35, 275-284.

Burns, W. M. (2002), Tectonics of the southern Andes from stratigraphic, thermochronologic, and geochemical perspectives, Ph.D. thesis, Cornell Univ., Ithaca, N. Y.

Burns, W. M., T. Jordan, P. Copeland, and S. Kelley (2006), The case for extensional tectonics in the Oligocene-Miocene southern Andes as recorded in the Cura Mallín basin $\left(36^{\circ}-38^{\circ} \mathrm{S}\right)$, in Evolution of an Andean Margin: A Tectonic and Magmatic View From the Andes to the Neuquén Basin $\left(35^{\circ}-39^{\circ} \mathrm{S}\right.$ latitude), edited by S. M. Kay and V. A. Ramos, Spec. Pap. Geol. Soc. Am., 407, 163-184, doi:10.1130/2006.2407(08)

Cahill, T., and B. Isacks (1992), Seismicity and shape of the subducted Nazca plate, J. Geophys. Res., 97, 17,503-17,529, doi:10.1029/92JB00493.

Cande, S. C., and R. B. Leslie (1986), Late Cenozoic tectonics of the southern Chile trench, J. Geophys. Res., 91, 471-496, doi:10.1029/JB091iB01p00471.

Charrier, R., et al. (2005), The Abanico extensional basin: Regional extension, chronology of tectonic inversion, and relation to shallow seismic activity and Andean uplift, Neues Jahrb. Geol. Palaeontol. Abh., 236(1-2), 43-77.

Clark, S. R., D. Stegman, and R. D. Müller (2008), Episodicity in back-arc tectonic regimes, Phys. Earth Planet. Inter., 171, 265-279, doi:10.1016/j. pepi.2008.04.012

Cobbold, P. R., and E. Rossello (2003), Aptian to recent compressionnal deformation, foothills of the Neuquén Basin, Argentina, Mar. Pet. Geol., 20, 429-443, doi:10.1016/S0264-8172(03)00077-1.

Cobbold, P. R., M. Diraison, and E. Rossello (1999), Bitumen veins and Eocene transpression, Neuquén Basin, Argentina, Tectonophysics, 314, 423-442, doi:10.1016/S0040-1951(99)00222-X.

Cobbold, P. R., E. A. Rossello, and F. O. Marques (2008), Where is the evidence for Oligocene rifting in the Andes? Is it in the Loncopué Basin of Argentina?, paper presented at 7 th International Symposium on Andean Geodynamics, Inst. de Rech. pour le Dv., Nice, France.

Coblentz, D. D., and R. M. Richardson (1996), Analysis of the South American interplate stress field, J. Geophys. Res., 101, 8643-8657, doi:10.1029/ 96JB00090.

Cowie, P. A., and C. H. Scholz (1992), Physical explanation for the displacement-length relationship of faults using a post-yield fracture mechanics model, J. Struct. Geol., 14(10), 1133-1148, doi:10.1016/ 0191-8141(92)90065-5.

Farr, T. G., et al. (2007), The Shuttle Radar Topography Mission, Rev. Geophys., 45, RG2004, doi:10.1029 2005RG000183.

Ferrer, J. (1982), Geologia (Recopilation para estudio regional suelo), map, scale 1:500,000, Cons. Fed. de Inver., Buenos Aires.

Folguera, A., T. Zapata, and V. A. Ramos (2006), Late Cenozoic extension and the evolution of the Neuquén Andes, in Evolution of an Andean Margin: A Tecton ic and Magmatic View From the Andes to the Neuquén Basin $\left(35^{\circ}-39^{\circ}\right.$ S latitude), edited by S. M. Kay and V. A. Ramos, Spec. Pap. Geol. Soc. Am., 407, 267-285, doi:10.1130/2006.2407(12)

Folguera, A., V. A. Ramos, T. Zapata, and M. G. Spagnuolo (2007a), Andean evolution at the Guañacos and Chos Malal fold and thrust belts $\left(36^{\circ} 30^{\prime}-37^{\circ} \mathrm{S}\right)$ J. Geodyn., 44, 129-148, doi:10.1016/j.jog. 2007.02.003.

Folguera, A., A. Introcaso, M. Giménez, F. Ruiz, P. Martinez, C. Tunstall, M. Garcia, and V. A. Ramos (2007b), Crustal attenuation in the southern Andean retroarc $\left(38^{\circ}-39^{\circ} 30^{\prime} \mathrm{S}\right)$ determined from tectonic and gravimetric studies: The Lonco-Luan asthenospheric anomaly, Tectonophysics, 439, 129-147, doi:10.1016/j.tecto.2007.04.001.

Folguera, A., G. Bottesi, V. A. Ramos, and T. Zapata (2008), Crustal collapse in the Andean backarc since $2 \mathrm{Ma}$ : Tromen volcanic plateau, southern central Andes (36 $\left.40^{\prime}-37^{\circ} 30^{\prime} \mathrm{S}\right)$, Tectonophysics, 459 , 140-160, doi:10.1016/j.tecto.2007.12.013.

Franzese, J. R., and L. A. Spalletti (2001), Late TriassicEarly Jurassic continental extension in southeastern Gondwana: Tectonic segmentation and pre-breakup rifting, J. South Am. Earth Sci., 14, 257-270, doi:10.1016/S0895-9811(01)00029-3.

Galland, O., P. R. Cobbold, J. de Bremond d'Ars, and E. Hallot (2007a), Rise and emplacement of magma during horizontal shortening of the brittle crust: Insights from experimental modeling, J. Geophys. Res., 112, B06402, doi:10.1029/2006JB004604.

Galland, O., E. Hallot, P. R. Cobbold, G. Ruffet, and J. de Bremond d'Ars (2007b), Volcanism in a compressional Andean settings: A structural and geochrono- logical study of the Tromen volcano (Neuquén province, Argentina), Tectonics, 26, TC4010, doi:10.1029/2006TC002011

Giambiagi, L. B., M. Tunik, and M. Ghiglione (2001), Cenozoic tectonic evolution of the Alto Tunuyán foreland basin above the transition zone between the flat and normal subduction segment $\left(33^{\circ} 30^{\prime}-\right.$ $\left.34^{\circ} \mathrm{S}\right)$, western Argentina, J. South Am. Earth Sci., 14(7), 707-724, doi:10.1016/S0895-9811(01) 00059-1.

Giambiagi, L. B., F. Bechis, V. García, and A. H. Clark (2008), Temporal and spatial relationships of thickand thin-skinned deformation: A case study from the Malargüe fold-and-thrust belt, southern central Andes, Tectonophysics, 459, 123-139, doi:10.1016/j.tecto.2007.11.069.

Groeber, P. (1929), Líneas fundamentales de la geología del Neuquén, sur de Mendoza y regiones adyacentes, Publ. 58, 110 pp., Minist. de Agric., Dir. General de Minas, Geol. y Hidrol., Buenos Aires.

Guillaume, B., J. Martinod, and N. Espurt (2009a), Variations of slab dip and overriding plate tectonics during subduction: Insights from analogue modelling, Tectonophysics, 463, 167-174, doi:10.1016/j. tecto.2008.09.043

Guillaume, B., J. Martinod, L. Husson, M. Roddaz, and R. Riquelme (2009b), Neogene uplift of central eastern Patagonia: Dynamic response to active spreading ridge subduction?, Tectonics, 28 , TC2009, doi:10.1029/2008TC002324.

Gutscher, M. A., R. Maury, J. P. Eissen, and E. Bourdon (2000a), Can slab melting be caused by flat subduction?, Geology, 28(6), 535-538, doi:10.1130/00917613(2000)28<535:CSMBCB $>2.0 . \mathrm{CO} ; 2$.

Gutscher, M. A., W. Spakman, H. Bijwaard, and E. R. Engdahl (2000b), Geodynamics of flat subduction: Seismicity and tomographic constraints from the Andean margin, Tectonics, 19, 814-833, doi:10.1029/ 1999TC001152.

Guzmán, C., E. Cristallini, and G. Bottesi (2007), Contemporary stress orientations in the Andean retroarc between $34^{\circ} \mathrm{S}$ and $39^{\circ} \mathrm{S}$ from borehole breakout analysis, Tectonics, 26, TC3016, doi:10.1029/ 2006TC001958.

Hampel, A., and A. Pfiffner (2006), Relative importance of trenchward upper plate motion and friction along plate motion and friction along plate interface for the topographic evolution of subduction-related mountain belts, in Analogue and Numerical Modelling of Crustal-Scale Processes, edited by S. J. H. Buiter and G. Schreurs, Geol. Soc. Spec. Publ., 253, 105115, doi:10.1144/GSL.SP.2006.253.01.05.

Heuret, A., and S. Lallemand (2005), Plate motions, slab dynamics and back-arc deformation, Phys. Earth Planet. Inter., 149, 31-51, doi:10.1016/j. pepi.2004.08.022. 
Heuret, A., F. Funiciello, C. Faccenna, and S. Lallemand (2007), Plate kinematics, slab shape and back-arc stress: A comparison between laboratory models and current subduction zones, Earth Planet. Sci. Lett., 256, 473-483, doi:10.1016/j.eps1.2007.02.004.

Holmberg, E. (1964), Descripción geológica de la Hoja 33d, Auca Mahuida (Provincia del Neuquén), Bol. 94, 88 pp., Dir. Nac. de Geol. y Miner., Buenos Aires.

Holmberg, E. (1976), Descripción geológica de la Hoja 32c, Buta Ranquil (Provincia del Neuquén), Bol. 152, 86 pp., Serv. Geol. Nac., Buenos Aires.

Horton, B. K., and P. G. DeCelles (1997), The modern foreland basin system adjacent to the central Andes, Geology, 25(10), 895-898, doi:10.1130/0091-7613 (1997)025<0895:TMFBSA $>2.3$. CO;2.

Humphrey, N. F., and S. K. Konrad (2000), River incision or diversion in response to bedrock uplift, Geology, 28(1), 43-46, doi:10.1130/0091-7613 (2000) $28<43$ :RIODIR $>2.0$.CO;2.

Jarrard, R. D. (1986), Relations among subduction parameters, Rev. Geophys., 24, 217-284, doi:10.1029/ RG024i002p00217.

Jordan, T., and R. W. Allmendinger (1986), The Sierras Pampeanas of Argentina: A modern analogue of Rocky Mountain foreland deformation, Am. J. Sci., 286(10), 737-764.

Jordan, T., R. W. Isacks, R. W. Allmendinger, J. A Brewer, V. A. Ramos, and C. J. Ando (1983), Andean tectonics related to geometry of subducted Nazca plate, Geol. Soc. Am. Bull., 94, 341-361, doi:10.1130/0016-7606(1983)94<341:ATRTGO>2.0. $\mathrm{CO} ; 2$

Jordan, T., W. Burns, R. Veiga, F. Pángaro, P. Copeland S. Kelley, and C. Mpodozis (2001), Extension and basin formation in the southern Andes caused by increased convergence rate: A mid-Cenozoic trigger for the Andes, Tectonics, 20, 308-324, doi:10.1029/1999TC001181.

Kahle, A. B., F. D. Palluconi, S. J. Hook, V. J. Realmuto, and G. Bothwell (1991), The advanced spaceborne thermal emission and reflectance radiometer (Aster), Int. J. Imaging Syst. Technol., 3(2), 144-156, doi:10.1002/ima.1850030210.

Kay, S. M. (2001), Tertiary to recent magmatism and tectonics of the Neuquén Basin between $36^{\circ} 05^{\prime}$ and $38^{\circ} \mathrm{S}$ latitude, technical report, Repsol-YPF, Buenos Aires.

Kay, S. M. (2002), Tertiary to recent transient shallow subduction zones in the central and southern Andes, paper presented at XV Congreso Geológico Argentino, Asoc. Geol. Argent., Calafate, Argentina.

Kay, S. M. (2005), Tertiary to recent evolution of Andean arc and backarc magmas between $36^{\circ} \mathrm{S}$ and $38^{\circ} \mathrm{S}$ and evidence for Miocene shallowing of the Nazca plate under the Neuquén basin, paper presented at 6th International Symposium on Andean Geodynamics, Inst. de Rech. pour le Dév., Barcelona, Spain.

Kay, S. M., and P. Copeland (2006), Early to middle Miocene backarc magmas of the Neuquén Basin: Geochemical consequences of slab shallowing and the westward drift of South America, in Evolution of an Andean Margin: A Tectonic and Magmatic View From the Andes to the Neuquén Basin $\left(35^{\circ}\right.$ $39^{\circ}$ S latitude), edited by S. M. Kay and V. A. Ramos, Spec. Pap. Geol. Soc. Am., 407, 185-213, doi:10.1130/2006.2407(09).

Kay, S. M., W. M. Burns, P. Copeland, and O. Mancilla 2006), Upper Cretaceous to Holocene magamatism and evidence for transient Miocene shallowing of the Andean subduction zone under the northern Neuquén Basin, in Evolution of an Andean Margin: A Tectonic and Magmatic View From the Andes to the Neuquén Basin (35 $-39^{\circ}$ S latitude), edited by S. M. Kay and V. A. Ramos, Spec. Pap. Geol. Soc. Am., 407, 19-60, doi:10.1130/2006.2407(02)

Keidel, J. (1925), Sobre la estructura tectónica de las capas petrolíferas en el Oriente del Territorio del Neuquén, Publ. 8, 67 pp., Minist. de Agric., Dir. General de Minas, Geol. y Hidrol., Buenos Aires.
Kendrick, E., M. Becis, R. Smalley Jr., B. Brooks, R. B. Vargas, E. Lauría, and L. P. Souto Fortes (2003), The Nazca-South America Euuler vector and its rate of change, J. South Am. Earth Sci., 16, 125131, doi:10.1016/S0895-9811(03)00028-2.

Kozlowski, E. E., C. E. Cruz, and C. A. Sylwan (1996), Geología estructural de la zona de Chos Malal, cuenca Neuquina, Argentina, paper presented at XIII Congreso Geológico Argentino y III Cingreso de Informaciones de Hydrocarburos, Asoc. Geol. Argent., Buenos Aires.

Lallemand, S., A. Heuret, and D. Boutelier (2005), On the relationships between slab dip, back-arc stress, upper plate absolute motion, and crustal nature in subduction zones, Geochem. Geophys. Geosyst., 6, Q09006, doi:10.1029/2005GC000917.

Lamb, S., and P. Davis (2003), Cenozoic climate change as a possible cause for the rise of the Andes, Nature, 425 (6960), 792-797, doi:10.1038/nature02049.

Lara, L. E., and A. Folguera (2006), The Pliocene to Quaternary narrowing of the southern Andean volcanic arc between $37^{\circ}$ and $41^{\circ} \mathrm{S}$ latitude, in Evolution of an Andean Margin: A Tectonic and Magmatic View From the Andes to the Neuquén Basin ( $35^{\circ}-39^{\circ}$ S latitude), edited by S. M. Kay and V. A. Ramos, Spec. Pap. Geol. Soc. Am., 407, 299-315, doi:10.1130/2006.2407(02).

Leanza, H. A., and C. A. Hugo (1999), Hoja Geológica 3969-I-Zapala, provincia del Neuquén, Bol. Inst. Geol. Recursos Nat., 275, 1-147.

Llambías, E. J. (1986), Intrusivos pérmicos del sur de la Cordillera del Viento, provincia del Neuquén, Asoc. Geol. Argent. Rev., 41, 22-32.

Llambías, E. J., and C. W. Rapela (1989), Las volcanitas de Collipilli, Neuquén $\left(37^{\circ} \mathrm{S}\right)$ y su relación con otras unidades paleógenas de la cordillera, Asoc. Geol. Argent. Rev., 44, 224-236.

Markham, B. L., W. C. Boncyk, D. L. Helder, and J. L. Barker (1997), Landsat-7 Enhanced Thematic Mapper plus radiometric calibration, Can. J. Remote Sens., 23(4), 289-419.

Marques, F. O., and P. R. Cobbold (2002), Topography as a major factor in the development of arcuate thrust belts: insights from sandbox experiments, Tectonophysics, 348, 247-268, doi:10.1016/ S0040-1951(02)00077-X.

Marques, F. O., and P. R. Cobbold (2006), Effects of topography on the curvature of fold-and-thrust belts during shortening of a 2-layer model of continental lithosphere, Tectonophysics, 415, 65-80, doi:10.1016/ j.tecto.2005.12.001

Meijer, P. T., R. Govers, and M. J. R. Wortel (1997), Forces controlling the present-day state of stress in the Andes, Earth Planet. Sci. Lett., 148, 157170, doi:10.1016/S0012-821X(97)00029-0.

Mosquera, A., and V. A. Ramos (2006), Intraplate deformation in the Neuquen Embayment, in Evolution of an Andean Margin: A Tectonic and Magmatic View From the Andes to the Neuquén Basin $\left(35^{\circ}\right.$ $39^{\circ}$ S latitude), edited by S. M. Kay and V. A. Ramos, Spec. Pap. Geol. Soc. Am., 407, 97-123, doi:10.1130/2006.2407(05)

Mpodozis, C., and S. M. Kay (1992), Late Paleozoic to Triassic evolution of the Gondwana margin: Evidence from Chilean Cordilleran batholiths $\left(28^{\circ}-31^{\circ} \mathrm{S}\right), \mathrm{Geol}$. Soc. Am. Bull., 104, 999-1014, doi:10.1130/00167606(1992)104<0999:LPTTEO > 2.3.CO;2.

Nivière, B., G. Messager, P. Lacan, and J. P. Xavier (2007), Interference between thick- and thinskinned tectonics along mountain fronts. Example of the Andean foothill (Neuquén basin, Argentina), Eos Trans. AGU, 88(52), Fall Meet. Suppl., Abstract T51D-0773

Norabuena, E., S. Dixon, S. Stein, and C. G. A. Harrison (1999), Decelerating Nazca-South America and Nazca-Pacific Plate motion, Geophys. Res. Lett., 26, 3405-3408, doi:10.1029/1999GL005394.

Oncken, O., D. Hindle, J. Kley, K. Elger, P. Victor, and K. Schemmann (2006), Deformation of the central Andean upper plate system-Facts, fiction, and constraints for plateau models, in The Andes-Active
Subduction Orogeny, edited by O. Oncken et al., pp. 3-27, Springer, Heidelberg, Germany.

Pardo-Casas, F., and P. Molnar (1987), Relative motion of the Nazca (Farallon) and South American plates since Late Cretaceous time, Tectonics, 6, 233-248, doi:10.1029/TC006i003p00233.

Ramos, V. A. (1976), Estratigrafia de los lagos Fontan y La Plata, paper presented at 18th Congreso Geologico Chileno, Santiago.

Ramos, V. A. (1978), Estructura, in geología y recursos naturales del Neuquén, paper presented at VII Congreso Geológico Argentino, Asoc. Geol. Argent., Neuquén, Relatorio, Argentina.

Ramos, V. A. (1981), Descripcion geologica de la Hoja $33 \mathrm{c}$, Los Chihuidos Norte, Provincia del Neuquén, Bol. 182, 103 pp., Serv. Geol. Nac., Buenos Aires.

Ramos, V. A. (1988), Tectonics of the Late Proterozoic-Early Paleozoic: A collisional history of southern South America, Episodes, 11, 168-174

Ramos, V. A., and A. Folguera (1999), Extension Cenozoica en la Cordillera Neuquina, paper presented at IV Congreso de Exploracion y Desarrollo de Hidrocarburos, Asoc. Argent. de Geól. Geofis. Petról. Mar del Plata, Argentina.

Ramos, V. A., and A. Folguera (2005), Tectonic evolution of the Andes of Neuquén: Constraints derived from the magmatic arc and foreland deformation, in The Neuquén Basin: A Case Study in Sequence Stratigraphy and Basin Dynamics, edited by G. D. Veiga et al., Geol. Soc. Spec. Publ., 252, 15-35, doi:10.1144/GSL.SP.2005.252.01.02

Ramos, V. A., and S. M. Kay (2006), Tectonic evolution of the southern central Andes, Mendoza and Neuquén, in Evolution of an Andean Margin: A Tectonic and Magmatic View From the Andes to the Neuquén Basin $\left(35^{\circ}-39^{\circ} \mathrm{S}\right.$ latitude), edited by S. M. Kay and V. A. Ramos, Spec. Pap. Geol. Soc. Am., 407, 1-17, doi:10.1130/2006.2407(01).

Ramos, V. A., M. Cegarra, and E. Cristallini (1996), Cenozoic tectonics of the High Andes of westcentral Argentina (30-36 $6^{\circ}$ latitude), Tectonophysics, 259, 185-200, doi:10.1016/0040-1951(95) $00064-\mathrm{X}$

Russo, R. M., and P. G. Silver (1996), Cordillera formation, mantle dynamics, and the Wilson Cycle, Geology, 24, 511-514, doi:10.1130/0091-7613(1996) $024<0511$ :CFMDAT $>2.3$. CO 2 .

Schellart, W. P. (2008), Overriding plate shortening and extension above subduction zones: A parametric study to explain formation of the Andes Mountains, Geol. Soc. Am. Bull., 120(11), 1441-1454, doi:10.1130/B26360.1.

Schellart, W. P., J. Freeman, D. R. Stegman, L. Moresi, and D. May (2007), Evolution and diversity of subduction zones controlled by slab width, Nature, 446, 308-311, doi:10.1038/nature05615.

Schellart, W. P., D. R. Stegman, and J. Freeman (2008), Global trench migration velocities and slab migration induced upper mantle volume fluxes: Constraints to find an Earth reference frame based on minimizing viscous dissipation, Earth Sci. Rev., 88, 118-144, doi:10.1016/j.earscirev.2008.01.005.

Schlische, R. W., S. S. Young, R. V. Ackermann, and A. Gupta (1996), Geometry and scaling relations of a population of very small rift-related normal faults, Geology, 24, 683-686, doi:10.1130/0091 7613(1996)024<0683:GASROA > 2.3.CO;2.

Sdrolias, M., and R. D. Müller (2006), Controls on back-arc basin formation, Geochem. Geophys. Geosyst., 7, Q04016, doi:10.1029/2005GC001090.

Silver, P. G., R. M. Russo, and C. Lithgow-Bertellon (1998), Coupling of South American and African plate motion and plate deformation, Science, 279, 60-63, doi:10.1126/science.279.5347.60.

Sobel, E. R., G. E. Hilley, and M. R. Strecker (2003) Formation of internally drained contractional basins by aridity-limited bedrock incision, J. Geophys Res., 108(B7), 2344, doi:10.1029/2002JB001883.

Somoza, R. (1998), Updated Nazca (Farallon)-South America relative motions during the last $40 \mathrm{My}$ : Implications for mountain building in the central 
Andean region, J. South Am. Earth Sci., 11(3), 211215, doi:10.1016/S0895-9811(98)00012-1.

Steinmann, G. (1929), Geologie von Peru, 448 pp., Carl Winters Univ. Buchhandlung, Heidelberg, Germany.

Stern, C. (1989), Pliocene to present migration of the volcanic front, Andean Southern Volcanic Front, Rev. Geol. Chile, 16(2), 145-162.

Uliana, M. A., K. T. Biddle, and J. J. Cerdan (1989), Mesozoic extension and the formation of Argentine sedimentary basins, in Extensional Tectonics and Stratigraphy of the North Atlantic Margins, edited by A. J. Tankard and H. R. Balkwill, $A A P G$ Mem., 46, 599-614.

Vergani, G., A. Tankard, H. J. Belotti, and H. J. Welsnik (1995), Tectonic evolution and paleogeography of the Neuquén Basin, Argentina, in Petroleum Basins of South America, edited by A. J. Tankard, A. J. Suerez, and H. J. Welsnik, AAPG Mem., 62, 383402.

Vietor, T., and H. Echtler (2006), Episodic Neogene southward growth of the Andean subduction orogen between $30^{\circ} \mathrm{S}$ and $40^{\circ} \mathrm{S}$ : Plate motions, mantle flow, climate, and upper plate structure, in The AndesActive Subduction Orogeny, edited by O. Oncken et al., pp. 375-400, Springer, Heidelberg, Germany.

Viñes, R. F. (1985), Estilos estructuralesen la Faja Plegada Occidental Neuquina, technical report, YPF, Buenos Aires.

Viñes, R. F. (1990), Productive duplex imbrication at the Neuquina Basin thrust belt front, Argentina, in Petroleum and Tectonics in Mobile Belts, edited by J. Letouzey, pp. 69-80, Technip, Paris.
Wichmann, R. (1934), Contribucíon an conocimiento geológico de los territorios del Neuquén y del Rio Negro, Bol. 39, 27 pp., Minist. de Agric., Dir. de Minas y Geol., Buenos Aires.

Windhausen, A. (1914), Contribucíon an conocimiento geológico de los territorios del Rio Negro y Neuquén, con su estudio de la región petroliferas de la parte central del Neuquén, Anales 10,60 pp., Minist. de Agric., Sect. Mineral. y Miner., Buenos Aires.

Yuan, X., G. Asch, K. Bataille, G. Bock, M. Bohm, H. Echtler, R. Kind, O. Oncken, and I. Wölbern (2006), Deep seismic images of the southern Andes, in Evolution of an Andean Margin: A Tectonic and Magmatic View From the Andes to the Neuquén Basin $\left(35^{\circ}-39^{\circ} \mathrm{S}\right.$ latitude), edited by S. M. Kay and V. A. Ramos, Spec. Pap. Geol. Soc. Am., 407, 61-72, doi:10.1130/2006.2407(03).

Zamora Valcarce, G., T. Zapata, D. del Pino, and A. Ansa (2006a), Structural evolution of the Agrio fold and thrust belt, in Evolution of an Andean Margin: A Tectonic and Magmatic View From the Andes to the Neuquén Basin $\left(35^{\circ}-39^{\circ}\right.$ S latitude), edited by S. M. Kay and V. A. Ramos, Spec. Pap. Geol. Soc. Am. 407, 125-145, doi:10.1130/2006.2407(06).

Zamora Valcarce, G., T. Zapata, A. Ansa, and G. Selva (2006b), Three-dimensionnal structural modeling and its application for development of the El Pórton field, Argentina, AAPG Bull., 90(3), 307-319, doi:10.1306/09300504142.

Zamora Valcarce, G., A. E. Rapalini, and C. M. Spagnuolo (2007), Reactivación de estructuras Cretácicas durante la deformación Miocena, faja plegada de Agrio, Neuquén, Rev. Assoc. Argent., 62(2), 299-307.

Zapata, T., I. Brissón, and F. Dzelalija (1999), La estructura de la faja plegada y corrida andina en relación con el control del basamento de la Cuenca Neuquina, Bol. Inf. Petrol., 60, 112-121.

Zapata, T. R., G. Zamora, and A. Ansa (2003), The Agrio fold and thrust belt: Structural analysis and its relationship with the petroleum system Vaca Muerta-Agrio-Troncoso inferior, paper presented at VIII Simposio Bolivariano: Exploracíon Petrolera en las Cuencas Subandinas, Cartagena, Colombia. Zöllner, W., and A. J. Amos (1973), Descripción geológica de la Hoja 32b, Chos Malal, Provincia del Neuquén, Bol. 143, 91 pp., Serv. Geol. Minero Argent., Buenos Aires.

P. Lacan, G. Messager, and B. Nivière, Modeling and Imagery in Geosciences, UMR 5212, CNRS, University of Pau, IPRA, BP 1155, F-64013 Pau CEDEX, France. (pierre.lacan@univ-pau.fr; gregoire. messager@etud.univ-pau.fr; bertrand.niviere@univpau.fr)

J. Martinod, LMTG, UMR 5563 UR 154, CNRS, IRD, University of Toulouse, 14 av. Edouard Belin, F-31400 Toulouse, France. (martinod@lmtg.obs-mip. fr)

J.-P. Xavier, CSTJF, Total, Avenue Larribau, F-64000 Pau, France. (jean-paul.xavier@total.com) 